\title{
Political appointees vs. career civil servants: A multiple principals theory of political bureaucracies
}

\author{
Pablo T. Spiller ${ }^{\mathrm{a}, *}$, Santiago Urbiztondo ${ }^{\mathrm{b}}$ \\ 'Haas School of Business, Berkeley, CA 94720, USA \\ ${ }^{b}$ Universidad Nacional de La Plata, Avda 7 No 776, 1900 La Plata, Argentina
}

Accepted for publication April 1994

\begin{abstract}
This paper analyzes a multiperiod delegation model with two principals and an agent. The purpose of the model is to explore the determinants of civil service structure, in particular, the use of political appointees (short lived agents) vs. civil servants (long lived agents). We see this process as a bargaining problem between two principals, Congress, a long lived principal, and the President, a short lived one. Our model is consistent with three aspects of the U.S. Civil Service: its evolution during this century, the high proportion of political appointees in the higher civil service with respect to its counterparts in occidental democracies with parliamentary systems, and the different scope of civil service coverage in local governments in the United States. We argue that these differences in the organization of civil services across countries and over time can be understood as the result of a game among multiple principals for the control of the bureaucracy, with the main determinants being the extent by which the legislative and executive bodies are aligned in their interests, who is politically more powerful, whether they have different political horizons, and to what extent political parties control their representatives at both the executive and legislative bodies. We model this interaction by letting the principals have different horizons. One principal lives through the entire game and faces a series of short lived principals. The emphasis of the model is on the choice of the agent, who can be either short or long lived.
\end{abstract}

\footnotetext{
* Corresponding author.

This paper was initially written while Urbiztondo was a Graduate Student, Department of Economics, University of Illinois. We would like to thank Lee Alston, Charlie Kahn, Jim Kuklinski, Peter Nardulli and seminar participants at the Instituto Torcuato Di Tella for helpful comments and suggestions.
} 
We analyze the optimal agent type from the perspective of each of the principals. Since a longer horizon agent can be better controlled by the long lived principal, the latter will prefer a long lived agent. The short lived principals, on the other hand, may prefer short or long lived agents. We show that if the two types of principals have opposed preferences in relation to the outcome of the agent's action, then the short lived principals will prefer a short lived agent. Otherwise, the short lived principal alive in the first period will also prefer long lived agents.

Keywords: Multiple principals; Civil service

JEL classification: $\mathrm{D} 72 ; \mathrm{H} 11$

Apart from differences of constituencies and goals, there is institutional rivalry between legislative and executive branches in the United States... Men in politics want to count for something, to have power, and our government is set up in a way that tends to pit legislature against executive. Though the truth is probably not quite so simple, it usually appears that as one waxes the other wanes. In sum, seeking to protect their power and to respond to their constituencies and to further the goals they value, legislature and executive so often face each other as competitors or opponents that it is easy to accept their opposition as fundamental. (Mainzer (1973, p. 74).)

\section{Introduction}

All political bureaucracies are not created equal. Some, like that of the modern US Federal system, are composed of tenured civil servants at the lower levels, and of mostly political appointees at the upper levels. On the other hand, political bureaucracies in parliamentary systems have relatively fewer political appointees at their upper levels. Similar differences can be found at other levels of government in the United States, where some political bureaucracies at the local level have relatively more political appointees than others, although, at all levels, there has been an evolutionary trend toward a decrease in the proportion of political appointees.

The main thrust of this paper is that differences in the organization of civil services can be understood as the result of a game among multiple principals for the control of the bureaucracy. While the bureaucracy is, in principle, directed by the executive branch of government, the legislature cannot be deterred from being involved in the determination of the policies the bureaucracy ought to follow. Thus, the bureaucracy has to respond to the interests of at least two political principals. These two principals, however, may differ in their political interests as well as in their political horizons. For example, from the beginning of this Century, U.S. legislators have tended to last substantially longer than presidents. Thus, the political horizons of legislators and Presidents have tended to diverge. 
Also, in the United States the two branches are usually not controlled by members of the same political party. This seems also to be the case for most other democracies based on the presidential system with strong legislative branches.

Patronage, or the use of political appointees at the high levels of office at the discretion of the executive, provides the latter with a bureaucracy that is, to a large extent, receptive to its interests. The legislature, on the other hand, prefers a bureaucracy that is more responsive to its own policy interests than to those of the relatively transient member of the executive. When legislators stay in power longer than presidents, they can use their expected longer presence to influence the bureaucracy in ways that the President, by staying in power only a relatively short period of time, may not credibly do. In particular, the legislators may tilt the interests of the bureaucracy by diminishing the ability of the President to appoint and/or remove bureaucrats. As a consequence, the only incentive schemes that the President can use are those than can be implemented during its tenure. The President cannot impose long term penalties nor rewards, as once the President's tenure expires any policy implemented during his or her administration may be revoked. On the other hand, legislators can credibly use incentive schemes that transcend the duration of the Presidential period. The use of such incentives tilts the interests of the bureaucracy towards the legislators' interests. Civil service provisions perform just that function. ${ }^{1}$ This basic insight is at the core of our explanation of the organization of civil services. ${ }^{2,3}$

We develop a three-actor-two-period game. In each period there are two principals and one agent. One of the principals (congress) is present in both periods, while we let the second principal (the president) rotate from period to period. The agent (the bureaucracy) takes actions in each period that cannot be observed by either principal, but that influence the probability of a particular event (higher bureaucratic effort brings down pollution levels, or decreases collusion, or brings down utility prices, etc). We explore the implications of making the agent be present in both periods (i.e., granting civil service protection) by analyzing the game under two circumstances: with a permanent agent and with a sequence of agents. We explore this model also under two types of assumptions concerning the principals' preferences. We first solve the model assuming that both prefer the

\footnotetext{
${ }^{1}$ Civil service provisions also have implications for incentives to invest in specific human capital. While these are important considerations, they are not useful in explaining the organizational differences discussed in the text. Thus, we do not consider them here. A model capturing those incentives is developed in Urbiztondo (1990).

${ }^{2}$ This view is also held by Wilson (1989), who notes that the US Congress was willing to give up the power to choose or replace public employees, among other reasons, because it was useful to restrict the president's power.

${ }^{3}$ This does not mean that both the President and Congressmen do not want to have public employees who fell intrinsically more identified with their objectives (call it political alignment). Nevertheless, given a particular ideological position of a public servant, the preferences of the chief executive and the legislature are claimed to depend on the length of time they will be in office.
} 
same policy outcome (e.g., low pollution levels, associated with higher bureaucratic effort), and we contrast the equilibrium to the one that arises when one of the principals (congress) prefers one particular outcome (e.g., low pollution), while the other principal prefers the opposite outcome.

The following empirical implications arise from our framework. First, if the executive and the legislature are usually composed of individuals with relatively similar policy preferences (i.e., when both members of Congress and the president share the same goals in terms of industry regulation, distribution of income, etc.), then patronage at relatively high levels of office does not confer the executive with any particular advantage over the legislature, as both would be better off with the use of long lived bureaucrats (i.e. civil servants). ${ }^{4}$ If, on the other hand, the executive and the legislature are usually composed of individuals with different and opposed preferences, then patronage confers the executive an advantage over civil service as it restricts the ability of the legislative branch to control the bureaucracy. In this case, then, we should expect patronage at high office levels to be more prevalent.

We model separation of powers by allowing the two principals to differ in their policy preferences. Parliamentary systems, by requiring the executive to be formed from the legislature, tend naturally to have more uniformity of preferences across the government and the legislature than presidential systems. Not all parliamentary systems, however, are alike. Electoral rules and party organization have substantial implications for the extent of commonality between government and legislatures. In particular, two party parliamentary systems, à la UK, Canada or Jamaica, will have the strongest extent of commonality between the legislature and the executive, as no coalitions are needed to maintain the government. Similarly, not all presidential systems are alike. Electoral rules here also make a difference. Disjoint presidential and legislative elections, as well as strong regional legislative representation tend to create preference divergences between the executive and the legislature. Thus, our first result suggests that patronage should be more prevalent in presidential than in parliamentary systems.

Our second result deals with political systems with separation of powers. In systems with separation of powers, the organization of the bureaucracy will tend to arise from a bargaining between the legislature and the executive. Thus, those countries in which the legislators' bargaining power in determining public policy, or interest in the actual performance of the bureaucracy, is relatively small would tend to organize the bureaucracy so that it serves mostly the interests of the executive branch. Thus, patronage should also be more prevalent. This result helps to explain differences across countries like Mexico or the US, where the constitu-

\footnotetext{
${ }^{4}$ The scope of this case should be interpreted with care. The alignment of the executive and the legislature does not include the case where the party in the executive has also the majority in the legislature, as in this case that political party would prefer to have political appointees in order to limit the influence of the minority party in Congress.
} 
tion and traditions have granted the legislature different levels of representativeness, and as a consequence, different levels of interests in the actual working of the bureaucracy.

These two empirical propositions help to explain the three features of civil service organization discussed at the beginning of the paper: the decline over time - during this Century - in the proportion of political appointees in the United States at the federal level, the relatively higher proportion of political appointees in the United States as compared to other occidental democracies, and finally, the different proportions of political appointees among cities of the United States. We explain these features by first, showing that over this Century, legislators' tenure started to increase, thus increasing their bargaining power vis-à-vis the President. At the same time, as public policy started to influence more directly the life of constituents, legislators local interests move away from patronage into policy, thus increasing their interests in the actual workings of the bureaucracy. Finally, different cities in the US have different forms of government. Some resemble parliamentary systems (i.e., no directly elected mayor), while others resemble presidential systems (i.e., have directly elected mayors). We use these similarities to explain their different use of patronage.

In the following sections we develop a multiple principals-multiple period model from which the empirical implications discussed above emerge. We then present some evidence concerning the organizational differences of civil services across countries, US cities and over time.

\section{The model}

In this section we develop a stylized model of delegation with two principals in a two-period setting. The principals differ in one significant way: one principal lives for two periods and faces a sequence of two short lived principals, each living for just one period. We assume the agent can be of two types: she lives either one or two periods. This framework is chosen so as to resemble the institutional features of government: a long lived legislature, a short lived executive and a bureaucrat who can be either a political appointee (i.e., short lived) or a career civil servant (i.e., long lived).

We are interested here in exploring the type of agent that each principal prefers. If both principals prefer a long lived agent, then a long lived agent being chosen. If, however, one prefers a long lived agent and the other prefers a short lived agent, then bargaining between the two principals for the nature of the agent may result in the selection of a short lived agent. While we do not model the nature of the bargaining game between the two principals for the type of agent ${ }^{5}$, our results suggest that short lived agents should have a higher probability of appearing in the

\footnotetext{
${ }^{5}$ Such bargaining game would depend on electoral and parliamentary rules not dealt with here.
} 
presence of principals with opposed interests. The reason being that in this case, at least one of the principals would like to have a short lived agent. This result has implications for our understanding of Civil Service structure. We assume that the decision about which type of agent to choose results from a bargaining game between the principals alive in period one, which is left unspecified. Long lived principals should prefer long lived agents. Since a long lived principal has an instrument not available to the short lived principal - a reward paid in a later period for a good performance in the earlier period - he may be able to better control the performance of a long lived agent. Although this is well documented in the (infinitely) repeated moral hazard literature (see for instance Radner (1985) and Rubinstein and Yaari (1983)), we show that there are circumstances under which this instrument is indeed used in equilibrium when a sequence of short lived principals interact with another long lived principal and a long lived agent in a two-period model.

We make several assumptions about the environment in which this game takes place. Four issues in particular are worth discussing: actions, technology, preferences and sequence. We describe them seriatim.

The game is of a moral hazard nature. Thus, agents take in each period (periods 1 and 2) an unobservable action, $e$. Their action has implications on the outcome that appear in each period, $x$. While the action $e$ is continuous, there are only two feasible outcomes in each period, a high outcome and a low outcome. Let $\boldsymbol{x}_{\boldsymbol{i}}$ represent the outcome in period $i$. Then, $x_{1}=\left\{x_{1}^{\mathrm{L}}, x_{1}^{\mathrm{h}}\right\}$ and $x_{2}=\left\{x_{2}^{\mathrm{L}}, x_{2}^{\mathrm{h}}\right\}$, where the subscripts denote the period and superscripts $L$ and $h$ denote low and high respectively. ${ }^{6}$ Let $\phi^{\mathrm{h}}(e)$ be the probability that the random variable $\tilde{x}$ equals $x^{\mathrm{h}}$ when the level of effort is $e$, where $\phi^{\mathrm{h}^{\prime}}(e)>0, \phi^{\mathrm{h}^{\prime}}(e)<0$ and $\phi^{\mathrm{L}}(e)=1-\phi^{\mathrm{h}}(e)$ represents the probability of a low outcome. ${ }^{7}$ Note that, since the equilibrium in period two can be a function of what happened in period one, we need to distinguish the variables in period two according to whether the outcome in period one was high or low. Therefore, $e_{2}^{\mathrm{h}}$ will denote effort level $e$ in period two after a high outcome in period one.

\footnotetext{
${ }^{6}$ Throughout the rest of the paper we refer to actions, transfers and preferences in a very abstract way. We have in mind the following concepts: the action is regulatory effort (which affects the outcome of the regulatory activity over which Congress - L - and successive presidents's $-S_{1}$ and $S_{2}$ - preferences are defined); Congress's transfers $\left(T_{\mathrm{L} 1}, T_{\mathrm{L} 2}\right.$ and $\left.R\right)$ are legislation affecting the agency (especially the Budget, i.e., maintaining or increasing the budget of the agency, which translates into a reward), appropriations, and painful hearings and investigations; finally, President's transfers $\left(T_{s 1}\right.$ and $T_{\mathrm{s} 2}$ ) are recommendations of pay raises and promotions, defense of the agencies programs, endowing the agency with autonomy, kindly treatment, etc. Accordingly, we disregard potential influence exerted by presidential vetoes over appropriations made by Congress (see Kiewiet and McCubbins (1988) for an analysis of this issue).

${ }^{7}$ Unless indicated otherwise, superscripts ' (") denote the first (second) derivative with respect to the argument that follows.
} 
In each period the principals attempt to control the agent by offering contingent transfers. To avoid very large penalties, we assume that these transfers cannot be negative. That is, both Congress and the president cannot extract penalties from the bureaucrats. We also assume that the principals are risk neutral while the agents are risk averse. The agent, however, does not have access to the credit market. ${ }^{8}$ For simplicity, we assume that the agents have separable utilities in income and effort, with the marginal disutility of effort being normalized to 1 .

We can express, then, the expected utility functions of the short lived principal alive in period 1 (called $S_{1}$ ), of the short lived principal alive in period 2 (called $S_{2}^{h}$ if the outcome in period one was high and $S_{2}^{L}$ if the outcome in period one was low) and of the long lived principal (called $L$ ) in the following way:

$$
\begin{aligned}
& \mathrm{E} U_{\mathrm{s} 1}=\phi^{\mathrm{L}}\left(e_{1}\right)\left[a x_{1}^{\mathrm{L}}-T_{\mathrm{s} 1}^{\mathrm{L}}\right]+\phi^{\mathrm{h}}\left(e_{1}\right)\left[a x_{1}^{\mathrm{h}}-T_{\mathrm{s} 1}^{\mathrm{h}}\right], \\
& \mathrm{E} U_{\mathrm{s} 2}^{j}=\phi^{\mathrm{L}}\left(e_{2}^{j}\right)\left[a x_{2}^{\mathrm{L}}-T_{\mathrm{s} 2}^{j \mathrm{~L}}\right]+\phi^{\mathrm{h}}\left(e_{2}^{j}\right)\left[a x_{2}^{\mathrm{h}}-T_{\mathrm{s} 2}^{j \mathrm{~h}}\right] \text { for } j=\mathrm{L}, \mathrm{h}, \\
& \mathrm{E} U^{\mathrm{L}}=\sum_{j=\mathrm{h}, \mathrm{L}} \phi^{j}\left(e_{1}\right)\left[b x_{1}^{j}-T_{\mathrm{L} 1}^{j}-R^{j}+\sum_{k=\mathrm{h}, \mathrm{L}} \phi^{k}\left(e_{2}^{j}\right)\left(b x_{2}^{k}-T_{\mathrm{L} 2}^{j k}\right)\right],
\end{aligned}
$$

where $a$ is the marginal utility $S_{1}, S_{2}^{\mathrm{h}}$ and $S_{2}^{\mathrm{L}}$ receive from $x$ and $b$ is the marginal utility $\mathrm{L}$ receives from $x ; T_{\mathrm{s} 1}=\left(T_{\mathrm{s1}}^{\mathrm{L}}, T_{\mathrm{s1}}^{\mathrm{h}}\right)$ is the transfer $\mathrm{S}_{1}$ offers to the agent when the outcome in the first period is $x_{\mathrm{L}}$ and $x_{\mathrm{h}}$ respectively; $T_{\mathrm{s} 2}^{\mathrm{h}}=$ $\left(T_{\mathrm{s} 2}^{\mathrm{Lh}}, T_{\mathrm{s} 2}^{\mathrm{hh}}\right)$ and $T_{\mathrm{s} 2}^{\mathrm{L}}=\left(T_{\mathrm{s} 2}^{\mathrm{LL}}, T_{\mathrm{s} 2}^{\mathrm{Lh}}\right)$ are similarly defined for $\mathrm{S}_{2}^{\mathrm{h}}$ and $\mathrm{S}_{2}^{\mathrm{L}} ;{ }^{9} T_{\mathrm{L} 1}=$ $\left(T_{\mathrm{L} 1}^{\mathrm{L}}, T_{\mathrm{L} 1}^{\mathrm{h}}\right)\left(T_{\mathrm{L} 2}^{\mathrm{h}}=\left(T_{\mathrm{L} 2}^{\mathrm{Lh}}, T_{\mathrm{L} 2}^{\mathrm{hh}}\right)\right.$ and $\left.T_{\mathrm{L} 2}^{\mathrm{L}}=\left(T_{\mathrm{L} 2}^{\mathrm{LL}}, T_{\mathrm{L} 2}^{\mathrm{Lh}}\right)\right)$ is the transfer $\mathrm{L}$ offers in the first (second) period depending on the observed outcome $x_{1}\left(x_{2}\right.$ after $x_{1}^{\mathrm{b}}$ and $x_{2}$ after $\left.x_{1}^{\mathrm{L}}\right)$, and $R=\left(R^{\mathrm{L}}, R^{\mathrm{h}}\right)$ is the reward L offers in the second period to the agent according to the outcome that occurred in period one. We let $b$ be positive, but $a$ can be either positive or negative (i.e., it could be the case that the short lived principals prefer a low level of effort.) Furthermore, the agent's utility at each period is given by

$$
U_{\mathrm{A} 1}=V\left(T_{\mathrm{L} 1}+T_{\mathrm{s} 1}\right)-e_{1}
$$

and

$$
U_{\mathrm{A} 2}=V\left(T_{\mathrm{L} 2}+T_{\mathrm{s} 2}+R\right)-e_{2},
$$

where $V(0)=0, V^{\prime}(T)>0$, and $V^{\prime \prime}(T)<0$ (i.e., the agent is averse to risk). Thus, the expected utility of an agent in period one is given by

$$
\mathrm{E} U_{\mathrm{A}}\left(e_{1}, e_{2}\right)=\mathrm{E} U_{\mathrm{A} 1}+\beta \mathrm{E} U_{\mathrm{A} 2},
$$

where $\beta$ represents the discount factor and expectations are taken with respect to $\phi(e) . \beta$ takes values zero and one: $\beta=0$ corresponds to a short lived agent, that

\footnotetext{
${ }^{8}$ This assumption is admittedly strong and to a certain extent drives the results of the model. It is, however, commonly used in agency models (see Rogerson (1985a)).

${ }^{9} T_{\mathrm{s} 2}^{\mathrm{Lh}}$, for example, represents $S_{2}^{\mathrm{L}}$ 's transfer when the outcome in period two is high.
} 
is, a political appointee, (called $A_{8}$ ) and $\beta=1$ to a long lived agent (called $A_{L}$ ), that is, a career civil servant. Since transfers are assumed to be nonnegative for both $x^{\mathrm{L}}$ and $x^{\mathrm{h}}$, the individual rationality constraints have to be satisfied in an ex-ante sense.

Note that since the transfers and the rewards have to be nonnegative and $b>0$, the long lived principal will effect zero transfers when $x=x^{\mathrm{L}}$ (i.e., $T_{\mathrm{L} 1}^{\mathrm{L}}=T_{\mathrm{L} 2}^{\mathrm{LL}}=$ $T_{\mathrm{L} 2}^{\mathrm{hL}}=R^{\mathrm{L}}=0$ ) unless the agent's individual rationality constraint is binding. Also, the different horizons of the two principals is here captured by the fact the long lived principal, $\mathrm{L}$, can commit in period 1 to a reward in period 2 according to the outcome that occurred in period $1 .{ }^{10}$ On the other hand, the short lived principal in period $1, S_{1}$, cannot. In the second period, though, both principals are short lived, as neither can offer transfers for the period ahead. Observe that if $L$ could not commit in period 1 to a compensation in period 2 , then $R^{\mathrm{h}}$ would be expected to be zero by the agent and it would not affect the development of the game in the second period.

Finally, we have to describe the timing of the model. It is as follows:

(1) $\mathrm{L}$ and $\mathrm{S}_{1}$ make simultaneous offers of $T_{\mathrm{L} 1}$ and $R$ and $T_{\mathrm{s} 1}$ respectively;

(2) A chooses $e_{1}$;

(3) $x_{1}$ results and transfers are effected;

(4) $\mathrm{L}$ and $\mathrm{S}_{2}$ make simultaneous offers of $T_{\mathrm{L} 2}$ and $T_{\mathrm{s} 2}$ respectively;

(5) A chooses $e_{2}$;

(6) $x_{2}$ results and transfers are effected.

Note that the principals in each period play a Nash game between them. As Eqs. (1) to (3) suggest, the reward $R^{\mathrm{h}}$ that $\mathrm{L}$ commits to give $\mathrm{A}_{\mathrm{L}}$ in the second period as a result of a high first period outcome makes $e_{2}, T_{\mathrm{L} 2}$ and $T_{\mathrm{s} 2}$ depend on $x_{1}$ as it is explained later in the paper. Denote $e_{2}^{\mathrm{h}^{*}}\left(e_{2}^{\mathrm{L}^{*}}\right)$ the equilibrium level of effort in period two if the outcome in period one was high (low). Therefore, the solution of the model is given by the $10^{\mathrm{t}}$-tuple $\left\{e_{1}^{*}, e_{2} K^{\mathrm{h}^{*}}, e_{2}^{\mathrm{L}^{*}}, T_{\mathrm{s} 1}^{*}, T_{\mathrm{L} 1}^{*}, T_{\mathrm{s} 2}^{\mathrm{h}^{*}}\right.$, $\left.T_{\mathrm{s} 2}^{\mathrm{L}^{*}}, T_{\mathrm{L} 2}^{\mathrm{L}^{*}}, T_{\mathrm{L} 2}^{\mathrm{L}^{*}}, R^{*}\right\}$, where

$$
e_{2}^{j^{*}}=\operatorname{argmax} \mathrm{E} U_{\mathrm{A} 2}^{j} \text { given } T_{\mathrm{s} 2}^{j^{*}}, T_{\mathrm{L} 2}^{j^{*}} \text { and } R^{j^{*}} \text { for } j=\mathrm{h}, \mathrm{L} ;
$$

( $\mathrm{A}_{2}^{j}$ 's problem)

$$
e_{1}^{*}=\operatorname{argmax} \mathrm{E} U_{\mathrm{A}} \text { given } e_{2}^{\mathrm{h}^{*}}, e_{2}^{\mathrm{I}^{*}}, T_{\mathrm{s} 1}^{*}, T_{\mathrm{L} 1}^{*}, T_{\mathrm{s} 2}^{*}, T_{\mathrm{L} 2}^{*} \text { and } R^{*} ;{ }^{11}
$$

( $A_{1}$ 's problem)

$$
T_{\mathrm{s} 1}^{*}=\operatorname{argmax} \mathrm{E} U_{\mathrm{s} 1}
$$

\footnotetext{
${ }^{10}$ Think of $L$ as giving $A_{L}$ a check at the end of period 1 that can only be cashed at the end of period 2 as long as $A$ is still working for $L$. The reward $R$, then, performs a similar role as a vesting pension plan.

${ }^{11}$ The dependence of $T_{\mathrm{s} 2}^{*}, T_{12}^{*}$ and $R^{*}$ on $x_{1}$ is omitted to simplify notation.
} 
subject to

$$
\begin{aligned}
& e_{1}^{*}, e_{2}^{\mathrm{h}^{*}}, e_{2}^{\mathrm{L}^{*}}, T_{\mathrm{L} 1}^{*}, T_{\mathrm{s} 2}^{*}, T_{\mathrm{L} 2}^{*}, R^{*}, \\
& \mathrm{E} U_{A}\left(e_{1}^{*}, e_{2}^{*}\right) \geqslant U_{A 1}^{*}+\beta U_{A 2}^{*},{ }^{12}
\end{aligned}
$$

and

$$
\begin{aligned}
& \phi^{\mathrm{b}}\left(e_{1}\right) \mathrm{E} U_{\mathrm{A} 2}\left(e_{2}^{\mathrm{h}}\right)+\phi^{\mathrm{L}}\left(e_{1}\right) \mathrm{E} U_{\mathrm{A} 2}\left(e_{2}^{\mathrm{L}}\right) \geqslant U_{2} . \\
& T_{\mathrm{s} 2}^{j^{*}}=\operatorname{argmax} \mathrm{E} U_{\mathrm{s} 2}^{j}
\end{aligned}
$$

subject to

$$
e_{2}^{j^{*}}, T_{\mathrm{L} 2}^{j^{*}}, R^{j^{*}}
$$

and

$$
\begin{aligned}
& \mathrm{E} U_{A 2}\left(e_{2}^{j^{*}}\right) \geqslant U_{2} \quad \text { for } j=\mathrm{h}, \mathrm{L} . \\
& T_{\mathrm{L} 1}^{*}, R^{*}=\operatorname{argmax} \mathrm{E} U_{\mathrm{L}},
\end{aligned}
$$

subject to

$$
\begin{aligned}
& e_{1}^{*}, e_{2}^{\mathrm{h}^{*}}, e_{2}^{\mathrm{L}}, T_{\mathrm{s} 1}^{*}, T_{\mathrm{s} 2}^{*}, T_{\mathrm{L} 2}^{*}, \\
& \mathrm{E} U_{\mathrm{A}}\left(e_{1}^{*}, e_{2}^{*}\right) \geqslant U_{\mathrm{A} 1}^{*}+\beta U_{\mathrm{A} 2}^{*},
\end{aligned}
$$

and

$$
\begin{aligned}
& \phi^{\mathrm{h}}\left(e_{1}\right) \mathrm{E} U_{2}^{\mathrm{A}}\left(e_{2}^{\mathrm{h}}\right)+\phi^{\mathrm{L}}\left(e_{1}\right) \mathrm{E} U_{2}^{\mathrm{A}}\left(e_{2}^{\mathrm{L}}\right) \geqslant U_{2}^{\mathrm{A} *} . \\
& T_{\mathrm{L} 2}^{j^{*}}=\operatorname{argmax} \mathrm{E} U_{\mathrm{L} 2}\left(x_{1}^{j}\right),
\end{aligned}
$$

subject to

$$
e_{2}^{j^{*}}, T_{\mathrm{s} 2}^{j^{*}}, R^{j^{*}}
$$

and

$$
\mathrm{E} U_{\mathrm{A} 2}\left(e_{2}^{j^{*}}\right) \geqslant U_{\mathrm{A} 2}^{*} \text { for } j=\mathrm{h}, \mathrm{L} .
$$

Thus, in equilibrium, the agent, in both periods, maximizes her utility given the transfers offered and also, in period one, given the equilibrium evolution of the game. The short lived principals maximize their utilities subject to the optimal reaction of the agent in their own period. Finally, the long lived principal maximizes his utility subject not only to the optimal reaction of the agent in the first period, but he also considers in period one his own equilibrium reaction in period two as well as that of the second period agent and the short lived principal.

\footnotetext{
${ }^{12}$ In what follows, $\operatorname{ICC}_{\mathrm{A} 1}$ and $\mathrm{IRC}_{\mathrm{A} 1}$ (ICC $\mathrm{IC}_{\mathrm{A} 2}$ and $\mathrm{IRC}_{\mathrm{A} 2}$ ) denote Incentive Compatibility Constraint and Individual Rationality Constraint of the agent in period one (two) respectively. $U_{\mathrm{A1}}^{*}\left(U_{\mathrm{A2}}^{*}\right)$ is the reservation value of the agent in period one (two), i.e., the utility she could obtain in case the contract is not signed.
} 
In other words, in period one, the short lived principal alive in period one, the long lived principal and the agent (if she is also long lived) maximize their utilities subject to the (expected) equilibrium evolution of the game in period two. The game in period two is played conditional on what happened in period one.

Given our assumptions about the stochastic production function $\phi(\mathrm{e})$, we can safely use the First Order Approach to solve this model. ${ }^{13}$ The agents' effort levels, $e_{1}, e_{2}^{\mathrm{b}}$ and $e_{2}^{\mathrm{L}}$ are then determined by the following first-order conditions:

$$
\phi^{h^{\prime}}\left(e_{1}\right)\left\{V\left(T_{\mathrm{s} 1}^{\mathrm{h}}+T_{\mathrm{L} 1}^{\mathrm{h}}\right)-V\left(T_{\mathrm{s} 1}^{\mathrm{L}}\right)+\beta \Delta \mathrm{E} U_{\mathrm{A} 2}^{\mathrm{h}}\left(R^{\mathrm{h}}\right)\right\}-1=0, \quad\left(\mathrm{ICC}_{\mathrm{A} 1^{\prime}}\right)
$$

and

$$
\begin{aligned}
& \phi^{j}\left(e_{1}\right)\left\{\phi^{\mathrm{h}^{\prime}}\left(e_{2}^{j}\right)\left[V\left(T_{\mathrm{s} 2}^{j \mathrm{~h}}+T_{\mathrm{L} 2}^{j \mathrm{~b}}+R^{j}\right)-V\left(T_{\mathrm{s} 2}^{j \mathrm{~L}}+R^{j}\right)\right]-1\right\}=0 \\
& \quad \text { for } j=\mathrm{h}, \mathrm{L},
\end{aligned}
$$

where

$$
\begin{aligned}
\Delta \mathrm{E} U_{\mathrm{A} 2}^{\mathrm{h}}\left(R^{\mathrm{h}}\right)= & \phi^{\mathrm{L}}\left(e_{2}^{\mathrm{h}}\right) V\left(T_{\mathrm{s} 2}^{\mathrm{hL}}+R^{\mathrm{h}}\right)+\phi^{\mathrm{h}}\left(e_{2}^{\mathrm{h}}\right) V\left(T_{\mathrm{L} 2}^{\mathrm{hh}}+T_{\mathrm{s} 2}^{\mathrm{hh}}+R^{\mathrm{h}}\right) \\
& -\phi^{\mathrm{L}}\left(e_{2}^{\mathrm{L}}\right) V\left(T_{\mathrm{s} 2}^{\mathrm{LL}}\right)-\phi^{\mathrm{h}}\left(e_{2}^{\mathrm{L}}\right) V\left(T_{\mathrm{L} 2}^{\mathrm{h}}-e_{2}^{\mathrm{L}}\right) \geqslant 0
\end{aligned}
$$

is the change in the agent's expected utility in period two following a high outcome in period one.

Note that, since $\phi^{h^{\prime}}($.$) is positive and V($.$) is concave, an interior solution$ develops only if

$$
T_{\mathrm{L} 2}^{\mathrm{Lh}}+T_{\mathrm{s} 2}^{\mathrm{Lh}}>T_{\mathrm{s} 2}^{\mathrm{LL}}, \quad T_{\mathrm{L} 2}^{\mathrm{hh}}+T_{\mathrm{s} 2}^{\mathrm{hh}}>T_{\mathrm{s} 2}^{\mathrm{hL}} \quad \text { and } \quad T_{\mathrm{L} 1}^{\mathrm{h}}+T_{\mathrm{s} 1}^{\mathrm{h}}>T_{\mathrm{s} 1}^{\mathrm{L}} \cdot{ }^{15}
$$

\section{A multiperiod single principal-single agent model}

Before solving the model, let us consider as a benchmark the case in which there is only one long lived principal (with expected utility $\mathrm{E} U_{\mathrm{p}}$ ) and one long lived agent. The purpose of this exercise is to show that there are conditions in which a long lived principal will prefer to deal with a long lived agent (i.e., that it is optimal for the principal to offer a second period reward). Here, the principal's problem is to maximize his profits subject to the agent's incentive compatibility constraints in periods one and two.

Assuming that the individual rationality constraints are not binding, the problem is given by $\operatorname{maxE} U_{\mathrm{p}}\left(T_{1}^{\mathrm{h}}, R^{\mathrm{h}}, T_{2}^{\mathrm{hh}}, T_{2}^{\mathrm{Lh}}\right)$ subject to $\operatorname{ICC}_{\mathrm{A} 1}^{\prime}, \mathrm{ICC}_{\mathrm{A} 2}^{\mathrm{L}^{\prime}}$ and $\mathrm{ICC}_{\mathrm{A} 2}^{\mathrm{h}^{\prime}}$

\footnotetext{
${ }^{13}$ See Rogerson (1985b).

${ }^{14}$ This change in utility cannot be negative, for otherwise the reward would have the effect of a punishment, and it would therefore be zero in equilibrium.

${ }^{15}$ This is assumed to be the case throughout the paper. For $\phi^{\mathrm{h}^{\prime}}(0)$ approaching infinity the first two inequalities are necessary and sufficient conditions, whereas the last one is sufficient but not necessary.
} 
with respect to $T_{1}^{\mathrm{h}}$ and $R^{\mathrm{h}}$, where $T_{2}^{\mathrm{hh}}$ and $T_{2}^{\mathrm{hh}}$ come from the principal's second period optimization. Since a positive reward affects the development of the game in the second period, the problem has to be solved backwards. ${ }^{16}$ Assuming an internal solution, the first-order conditions with respect to $e_{2}^{\mathrm{h}}, T_{2}^{\mathrm{hh}}$ and $\lambda_{2}^{\mathrm{h}}$ (the Lagrange multiplier associated with $\mathrm{ICC}_{\mathrm{A} 2}^{\mathrm{h}^{\prime}}$ ) characterize the equilibrium in the second period:

$$
\begin{aligned}
& e_{2}^{\mathrm{h}}: \phi^{\mathrm{h}^{\prime}}\left(e_{2}^{\mathrm{h}}\right)\left[b\left(x_{2}^{\mathrm{h}}-x_{2}^{\mathrm{L}}\right)-T_{2}^{\mathrm{hh}}\right] \\
& \quad+\lambda_{2}^{\mathrm{h}} \phi^{\mathrm{h}^{\prime \prime}}\left(e_{2}^{\mathrm{h}}\right)\left[V\left(T_{2}^{\mathrm{hh}}+R^{\mathrm{h}}\right)-V\left(R^{\mathrm{h}}\right)\right]=0, \\
& T_{2}^{\mathrm{hh}}:-\phi^{\mathrm{h}}\left(e_{2}^{\mathrm{h}}\right)+\lambda_{2}^{\mathrm{h}} \phi^{\mathrm{h}^{\prime}}\left(e_{2}^{\mathrm{h}}\right) V^{\prime}\left(T_{2}^{\mathrm{hh}}+R^{\mathrm{h}}\right)=0, \\
& \lambda_{2}^{\mathrm{h}}: \phi^{\mathrm{h}^{\prime}}\left(e_{2}^{\mathrm{h}}\right)\left[V\left(T_{2}^{\mathrm{hh}}+R^{\mathrm{h}}\right)-V\left(R^{\mathrm{h}}\right)\right]-1=0 .
\end{aligned}
$$

Complete differentiation of this system of equations allows us to obtain the reaction of $e_{2}^{\mathrm{h}}$ and $T_{2}^{\mathrm{hh}}$ as $R^{\mathrm{h}}$ changes. We show in the appendix, Section A.1, that for utility functions displaying nonincreasing risk-aversion the equilibrium level of effort in period two is a decreasing function of $R^{\mathrm{h}}$, whereas $T_{2}^{\text {hh }}$ increases with $R^{\text {h }}$.

We now proceed to solve the problem of the principal in period one. Let $e_{2}^{\mathrm{h}^{*}}=g\left(R^{\mathrm{h}}\right)$ and $T_{2}^{* \text { hh }}=f\left(R^{\mathrm{b}}\right)$, with $g^{\prime}\left(R^{\mathrm{h}}\right)<0$ and $f^{\prime}\left(R^{\mathrm{h}}\right)>0$ for $R^{\mathrm{h}} \geqslant 0$. Then the problem becomes

$\max \mathrm{E} U_{p}\left(T_{1}^{\mathrm{h}}, R^{\mathrm{h}}, f\left(R^{\mathrm{h}}\right), g\left(R^{\mathrm{h}}\right)\right)$ with respect to $e_{1}, T_{1}^{\mathrm{h}}$ and $R^{\mathrm{h}}$,

subject to $\operatorname{ICC}_{A 1}^{\prime}, \operatorname{ICC}_{A 2}^{\mathrm{L}^{\prime}}$ and $\mathrm{ICC}_{A 2}^{\mathrm{L}^{\prime}} \cdot{ }^{17}$

Replacing $\lambda_{1}$ and $\lambda_{2}^{\mathrm{h}}$ (the Lagrange multipliers associated with $\mathrm{ICC}_{\mathrm{A} 1}^{\prime}$ and $\mathrm{ICC}_{\mathrm{A} 2}^{\mathrm{h}^{\prime}}$ ) from the first-order conditions in the first and second periods respectively, and using the envelope theorem, the first-order condition with respect to $R^{\mathrm{h}}$ becomes

$$
\begin{aligned}
& \phi^{\mathrm{h}}\left(e_{1}\right)\left[-1+\beta \phi^{\mathrm{L}}\left(e_{2}^{\mathrm{h}}\right) \frac{V^{\prime}\left(R^{\mathrm{h}}\right)}{V^{\prime}\left(T_{1}^{\mathrm{h}}\right)}+\phi^{\mathrm{h}}\left(e_{2}^{\mathrm{h}}\right)\right. \\
& \left.\times\left(\beta \frac{V^{\prime}\left(T_{2}^{\mathrm{hh}}+R^{\mathrm{h}}\right)}{V^{\prime}\left(T_{1}^{\mathrm{h}}\right)}+1-\frac{V^{\prime}\left(R^{\mathrm{h}}\right)}{V^{\prime}\left(T_{2}^{\mathrm{hh}}+R^{\mathrm{h}}\right)}\right)\right] \\
& +\phi^{\mathrm{h}}\left(e_{1}\right) \phi^{\mathrm{h}}\left(e_{2}^{\mathrm{h}}\right) \beta \frac{V^{\prime}\left(T_{2}^{\mathrm{hh}}+R^{\mathrm{h}}\right)}{V^{\prime}\left(T_{1}^{\mathrm{h}}\right)} f^{\prime}\left(R^{\mathrm{h}}\right)=0 .
\end{aligned}
$$

\footnotetext{
${ }^{16}$ Note that the equilibrium in period two depends on $R^{\mathrm{h}}$ only if $x_{1}=x_{1}^{\mathrm{h}}$. Therefore, we concentrate on the equilibrium in period two given that a high outcome occurred in period one.

${ }^{17}$ See the appendix for a more detailed statement of the problem.
} 
We can now state the following Lemma.

Lemma 1. A sufficient condition for the equilibrium $R^{\mathrm{h}}$ to be positive is that $\phi^{\mathrm{b}}(e)<1 / 2$.

Proof. We show this by contradiction. Assume first that $R^{\mathrm{h}}=0$. If this is the case the two periods are separated and $e_{2}^{\mathrm{h}}=e_{2}^{\mathrm{L}}$ and $T_{1}^{\mathrm{h}}=T_{2}^{\mathrm{h}}$. From the first-order condition with respect to $R^{\mathrm{h}}$ corner solution (i.e., $R^{\mathrm{b}}=0$ ) requires that

$$
\left[1-\phi^{\mathrm{h}}(e)(1+\beta)\right] \geqslant \frac{V^{\prime}(0)}{V^{\prime}\left(T^{\mathrm{b}}\right)}\left[\beta-\phi^{\mathrm{h}}(e)(1+\beta)\right]+\beta \phi^{\mathrm{h}}(e) f^{\prime}(0) .
$$

Let $\beta=1{ }^{18}$ Since $V^{\prime}(0) / V^{\prime}\left(T^{\mathrm{h}}\right)>1$ for $T^{\mathrm{b}}>0$, this condition is satisfied only if $\phi^{\mathrm{h}}(e) \geqslant 1 / 2 .{ }^{19}$ Thus, since $R^{\mathrm{h}}=0$ implies that $e$ is determined in a one period principal-agent problem, situations in which the solution to the one period problem involve the implementation of a level of effort that results in $\phi^{\mathrm{h}}(e)<1 / 2$ produce a contradiction, implying that (at least) in those cases a positive reward emerges in equilibrium. ${ }^{20}$ In footnote 20 we show that those instances do exist. ${ }^{21}$

\section{Characterization of the solution when the principals' preferences are aligned}

In this section we limit the analysis to cases where the principals' preferences are aligned, so that both prefer a high outcome in every period (i.e., $a>0$ ). This would, for example, be the case where both the President and Congress want the regulatory agency to put more effort in price regulation or pollution control, or when the cabinet is composed of members of the legislature. ${ }^{22}$

The central aspect of the problem is to determine if a long lived agent (i.e., a career civil servant) will be employed. We analyze this question by determining

\footnotetext{
${ }^{18}$ Note that this equation is unambiguously satisfied as $\beta$ approaches zero.

${ }^{19}$ This is a necessary, but not sufficient, condition due to the fact that $f^{\prime}(0)>0$.

${ }^{20}$ To interpret this condition, note that a sufficient condition for a marginal $R^{\mathrm{b}}$, evaluated at $R^{\mathrm{b}}=0$, to increase $e_{1}$ by more than it reduces $e_{2}^{\text {h }}$ (in expected sense), ceteris paribus (i.e., holding the transfers constant), is that $\phi^{\mathrm{h}}(e)<1 / 2$. The reward, then, can increase the expected level of aggregated effort. A proof of this result is available from the authors upon request.

${ }^{21}$ Let, for example, $\phi^{\mathrm{h}}(e)=2-e^{-1}, e \in(1 / 2,1)$ (so that $\phi^{\mathrm{h}}(e) \in(0,1)$ ) and $V(T+R)=$ $-c^{-d(T+R)}$ (where $c$ and $d$ are two positive constants, and $d$ is the Arrow-Pratt measure of absolute risk-aversion). It can then be easily checked that, for instance, letting $c=2, d=b=1$, and $x^{\mathrm{b}}-x^{\mathrm{L}}=1$, the equilibrium level of effort is $e=0.62$ (and then $\phi^{\mathrm{h}}(e)=0.387$ ), which results in a contradiction to $R^{\text {h }}=0$.

${ }^{22}$ For simplicity we also assume that the agents' individual rationality constraints are not binding in either period.
} 
whether, in equilibrium, a positive reward is offered to be paid in the second period following a high outcome in the first. If a reward is offered the implementability of a given level of effort in the second period is more difficult as the agent is wealthier and, because of the concavity of her utility function, has a lower marginal utility of money. On the other hand, the reward also diminishes the cost of implementing an action in the first period. This being the case, the short lived principal alive in period one is benefitted by the use of the reward by the long lived principal, whereas the short lived principal alive in the second period is harmed. Accordingly, $S_{1}$ prefers a long lived agent (i.e., a career civil servant) while $S_{2}$ would prefer a short lived agent (i.e., a political appointee).

Note that for $a>0$, as long as the individual rationality constraints are not binding, $T_{\mathrm{s} 1}^{\mathrm{L}}=T_{\mathrm{s} 2}^{\mathrm{L}}=0$. Thus, the first-order condition to $\mathrm{S}_{1}$ 's problem (i.e., choosing its first-period transfer), results in

$$
\frac{1}{V^{\prime}\left(T_{\mathrm{s} 1}^{\mathrm{h}}+T_{\mathrm{L} 1}^{\mathrm{h}}\right)}=\lambda_{\mathrm{s} 1} \frac{\phi^{\mathrm{h}^{\prime}}\left(e_{1}\right)}{\phi^{\mathrm{h}}\left(e_{1}\right)},
$$

where $\lambda_{\mathrm{s} 1}$ is the Lagrange multiplier of the agent's incentive compatibility constraint faced by the short lived principal in the first period and is given by

$$
\lambda_{\mathrm{s} 1}=\frac{-\phi^{\mathrm{h}^{\prime}}\left(e_{1}\right)\left[a\left(x_{1}^{\mathrm{h}}-x_{1}^{\mathrm{L}}\right)-T_{\mathrm{s} 1}^{\mathrm{h}}\right]}{\phi^{\mathrm{h}^{\prime \prime}}\left(e_{1}\right)\left[V\left(T_{\mathrm{s} 1}^{\mathrm{h}}+T_{\mathrm{L} 1}^{\mathrm{h}}\right)+\beta \Delta \mathrm{E} U_{\mathrm{A} 2}^{\mathrm{h}}\left(R^{\mathrm{h}}\right)\right]} .
$$

with

$$
\begin{aligned}
\Delta \mathrm{E} U_{\mathrm{A} 2}^{\mathrm{h}}\left(R^{\mathrm{h}}\right)= & \phi^{\mathrm{L}}\left(e_{2}^{\mathrm{h}}\right) V\left(R^{\mathrm{h}}\right)+\phi^{\mathrm{h}}\left(e_{2}^{\mathrm{h}}\right) V\left(T_{\mathrm{L} 2}^{\mathrm{hh}}+T_{\mathrm{s} 2}^{\mathrm{hh}}+R^{\mathrm{h}}\right) \\
& -\phi^{\mathrm{h}}\left(e_{2}^{\mathrm{L}}\right) V\left(T_{\mathrm{L} 2}^{\mathrm{Lh}}+T_{\mathrm{s} 2}^{\mathrm{Lh}}\right)-\left(e_{2}^{\mathrm{h}}-e_{2}^{\mathrm{L}}\right) \geqslant 0 .
\end{aligned}
$$

As the above equation shows, $\partial \lambda_{\mathrm{s} 1} / \partial \beta$ is negative, meaning that if the agent is long lived (i.e., if $\beta=1$ ), a given level of effort can be implemented with a lower total transfer $\left(T_{\mathrm{s} 1}^{\mathrm{h}}+T_{\mathrm{L} 1}^{\mathrm{h}}\right)$. That is, $\mathrm{S}_{1}$ receives a positive externality from a positive reward $R^{\mathrm{b}}$.

As we explained in the previous section, the long lived principal's problem in period one takes into account the evolution of the game in period two after a reward was granted. We solve the model backwards. The equilibrium in period two (after $x_{1}^{\mathrm{b}}$ occurred in period one) is characterized by the following system of equations:

$$
\begin{aligned}
& -\phi^{\mathrm{h}}\left(e_{2}^{\mathrm{h}}\right)-\frac{\phi^{\mathrm{h}^{\prime}}\left(e_{2}^{\mathrm{h}}\right)^{2}\left[b\left(x_{2}^{\mathrm{h}}-x_{2}^{\mathrm{L}}\right)-T_{\mathrm{L} 2}^{\mathrm{hh}}\right] V^{\prime}\left(T_{\mathrm{s} 2}^{\mathrm{hh}}+T_{\mathrm{L} 2}^{\mathrm{hh}}+R^{\mathrm{h}}\right)}{\phi^{\mathrm{h}^{4}}\left(e_{2}^{\mathrm{h}}\right)\left[V\left(T_{\mathrm{L} 2}^{\mathrm{hh}}+T_{\mathrm{s} 2}^{\mathrm{hh}}+R^{\mathrm{h}}\right)-V\left(R^{\mathrm{b}}\right)\right]}=0, \\
& -\phi^{\mathrm{h}}\left(e_{2}^{\mathrm{h}}\right)-\frac{\phi^{\mathrm{h}^{\prime}}\left(e_{2}^{\mathrm{h}}\right)^{2}\left[a\left(x_{2}^{\mathrm{h}}-x_{2}^{\mathrm{L}}\right)-T_{\mathrm{s} 2}^{\mathrm{hh}}\right] V^{\prime}\left(T_{\mathrm{s} 2}^{\mathrm{hh}}+T_{\mathrm{L} 2}^{\mathrm{hh}}+R^{\mathrm{h}}\right)}{\phi^{\mathrm{h}^{\prime \prime}}\left(e_{2}^{\mathrm{h}}\right)\left[V\left(T_{\mathrm{L} 2}^{\mathrm{hh}}+T_{\mathrm{s} 2}^{\mathrm{hh}}+R^{\mathrm{h}}\right)-V\left(R^{\mathrm{h}}\right)\right]}=0, \\
& \phi^{\mathrm{h}^{\prime}}\left(e_{2}^{\mathrm{h}}\right)\left[V^{\prime}\left(T_{\mathrm{s} 2}^{\mathrm{hh}}+T_{\mathrm{L} 2}^{\mathrm{hh}}+R^{\mathrm{h}}\right)-V\left(R^{\mathrm{h}}\right)\right]-1=0,
\end{aligned}
$$


where the first equation results from $L_{2}^{\mathrm{h}}$ 's problem (combining the first-order conditions with respect to $T_{\mathrm{L} 2}^{\mathrm{bb}}$ and $e_{2}^{\mathrm{b}}$ ), the second equation is similarly obtained from $S_{2}^{h}$ 's problem and the last one is the (common) first order condition with respect to the Lagrange multiplier (i.e., $\operatorname{ICC}_{\mathrm{Az}^{\prime}}^{\mathrm{h}^{\prime}}$ ).

Here again, as in the case of one single principal, we can obtain the reaction of $T_{\mathrm{L} 2}^{\mathrm{hh}}, T_{\mathrm{s} 2}^{\mathrm{hh}}$ and $e_{2}^{\mathrm{h}}$ to changes in $R^{\mathrm{h}}$. In the appendix, Section A.2, we show that the equilibrium level of effort in period two is a decreasing function of the reward, whereas both $T_{\mathrm{L} 2}^{\mathrm{bh}}$ and $T_{\mathrm{s} 2}^{\mathrm{bh}}$ increase with $R^{\mathrm{b}}$. ${ }^{23}$ These reactions are considered by the long lived principal, who in period one maximizes $\mathrm{E} U_{\mathrm{L}}\left(T_{\mathrm{L} 1}^{\mathrm{h}}, R^{\mathrm{h}}\right)$ subject to $\mathrm{ICC}_{\mathrm{A} 1}^{\prime}$, ICC $\mathrm{A}_{\mathrm{A} 2}^{\mathrm{h}}$, and the optimal responses of $\mathrm{S}_{2}^{\mathrm{h}}$ and $\mathrm{L}_{2}^{\mathrm{h}}$. As before, let $T_{\mathrm{L} 2}^{\mathrm{hh}}=f\left(R^{\mathrm{h}}\right)$ and $T_{\mathrm{s} 2}^{\mathrm{hh}}=h\left(R^{\mathrm{h}}\right)$, with $f^{\prime}\left(R^{\mathrm{h}}\right)>0$ and $h^{\prime}\left(R^{\mathrm{h}}\right)>0$ for $R^{\mathrm{h}} \geqslant 0$. Then the long lived principal's problem in the first period becomes

$\operatorname{maxE} U_{\mathrm{L}}\left(T_{1}^{\mathrm{h}}, R^{\mathrm{h}}, f\left(R^{\mathrm{h}}\right), h\left(R^{\mathrm{h}}\right)\right)$, with respect to $e_{1}, T_{1}^{\mathrm{h}}$ and $R^{\mathrm{h}}$, subject to $\mathrm{ICC}_{\mathrm{A} 1}^{\prime}, \mathrm{ICC}_{\mathrm{A} 2}^{\mathrm{L}^{\prime}}$ and $\mathrm{ICC}_{\mathrm{A} 2}^{\mathrm{h}^{\prime}}$.

Since both $f^{\prime}\left(R^{\mathrm{h}}\right)$ and $h^{\prime}\left(R^{\mathrm{b}}\right)$ are positive for $R^{\mathrm{b}} \geqslant 0$, to prove that there are cases for which this solution is interior requires exactly the same argument provided in Lemma 1 above and we omit it here. Once again, a sufficient condition for $R^{\mathrm{b}}>0$ is that $\phi^{\mathrm{h}}(e)<1 / 2$ in the one period game. Thus, under conditions similar to those specified in Section 3, a reward is offered in equilibrium when the agents' individual rationality constraints are not binding.

To conclude this section, we note again that since a reward reduces the marginal cost of implementing a level of effort in period one, both $S_{1}$ and $L$ prefer a long lived agent. On the other hand, since a reward makes the implementation of a level of effort more costly in the second period, $S_{2}$ prefers a short lived agent. We state this result in Proposition 1 below.

Proposition 1. The equilibrium to the game described in Section II when L, $S_{1}$ and $S_{2}$ prefer a high outcome and the agents' individual rationality constraints are not binding involves a positive reward given by $L$, which in turns leaves $L$ and $S_{1}$ both preferring to deal with $A_{L}$ and $S_{2}$ preferring to deal with $A_{s}$.

\section{Characterization of the solution when the principals' preferences are opposed}

In this section we analyze the solution when the principals' preferences are opposed under the assumption that the individual rationality constraints are still not binding. This case is meant to capture the Presidential system with division of

\footnotetext{
${ }^{23}$ It becomes obvious here that $S_{2}$ prefers a short lived agent, since as $R^{\text {h }}$ increases he pays a higher transfer for a lower action.
} 
powers, where the same party does not have full control over both branches of government. We capture the principals' opposed preferences by letting $a$ be negative and $b$ positive. ${ }^{24}$ As in the previous section, we explore the choice of bureaucrats by determining whether the short lived principals prefer to deal with short lived agents or not.

Note that now $T_{\mathrm{s} 1}^{\mathrm{h}}=T_{\mathrm{s} 2}^{\mathrm{h}}=T_{\mathrm{L} 1}^{\mathrm{L}}=T_{\mathrm{L} 2}^{\mathrm{L}}=R^{\mathrm{L}}=0$. The equilibrium in the second period (after a high outcome in period one) is then characterized by the following system of equations:

$$
\begin{aligned}
& -\phi^{\mathrm{h}}\left(e_{2}^{\mathrm{h}}\right)-\frac{\phi^{\mathrm{h}^{\prime}}\left(e_{2}^{\mathrm{h}}\right)^{2}\left[b\left(x_{2}^{\mathrm{h}}-x_{2}^{\mathrm{L}}\right)-T_{\mathrm{L} 2}^{\mathrm{hh}}\right] V^{\prime}\left(T_{\mathrm{L} 2}^{\mathrm{hh}}+R^{\mathrm{h}}\right)}{\phi^{\mathrm{h}^{\prime \prime}}\left(e_{2}^{\mathrm{h}}\right)\left[V\left(T_{\mathrm{L} 2}^{\mathrm{hh}}+R^{\mathrm{h}}\right)-V\left(T_{\mathrm{s} 2}^{\mathrm{hL}}+R^{\mathrm{h}}\right)\right]}=0, \\
& -\phi^{\mathrm{L}}\left(e_{2}^{\mathrm{h}}\right)-\frac{\phi^{\mathrm{h}^{\prime}}\left(e_{2}^{\mathrm{h}}\right)^{2}\left[a\left(x_{2}^{\mathrm{L}}-x_{2}^{\mathrm{h}}\right)-T_{\mathrm{s} 2}^{\mathrm{hL}}\right] V^{\prime}\left(T_{\mathrm{s} 2}^{\mathrm{hL}}+R^{\mathrm{h}}\right)}{\phi^{\mathrm{h}^{\prime}}\left(e_{2}^{\mathrm{h}}\right)\left[V\left(T_{\mathrm{L} 2}^{\mathrm{hh}}+R^{\mathrm{h}}\right)-V\left(T_{\mathrm{s} 2}^{\mathrm{hL}}+R^{\mathrm{h}}\right)\right]}=0, \\
& \phi^{\mathrm{h}^{\prime}}\left(e_{2}^{\mathrm{h}}\right)\left[V\left(T_{\mathrm{L} 2}^{\mathrm{hh}}+R^{\mathrm{h}}\right)-V\left(T_{\mathrm{s} 2}^{\mathrm{hL}}+R^{\mathrm{h}}\right)\right]-1=0,
\end{aligned}
$$

where the first equation results from $L_{2}^{\mathrm{h}}$ 's problem (combining the first-order conditions with respect to $T_{\mathrm{L} 2}^{\mathrm{hh}}$ and $e_{2}^{\mathrm{b}}$ ), the second equation is similarly obtained

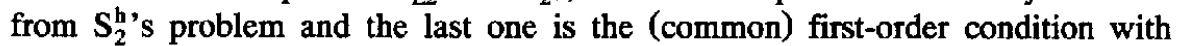
respect to the Lagrange multiplier (i.e., ICC $\mathrm{A}^{\mathrm{h}^{\prime}}$ ). Here again, as in the case of aligned interests, we can obtain the reactions of $T_{\mathrm{L} 2}^{\mathrm{hh}}, T_{\mathrm{s} 2}^{\mathrm{LL}}$ and $e_{2}^{\mathrm{h}}$ to changes in $R^{\mathrm{h}}$. In the appendix, Section A.3, we show that $e_{2}^{\mathrm{h}}$ and $T_{\mathrm{s} 2}^{\mathrm{hL}}$ are decreasing functions of the reward, whereas $T_{\mathrm{L} 2}^{\mathrm{hh}}$ increases $R^{\mathrm{h}} .{ }^{25}$

Considering these reactions in the second period, we can now solve the problem of the long lived principal, who in period one maximizes $\mathrm{E} U_{\mathrm{L}}\left(T_{\mathrm{L} 1}^{\mathrm{h}}, R^{\mathrm{h}}\right)$ subject to $\mathrm{ICC}_{\mathrm{A} 1}^{\prime}, \mathrm{ICC}_{\mathrm{A} 2}^{\mathrm{h}^{\prime}}$, and the optimal responses of $\mathrm{S}_{2}^{\mathrm{h}}$ and $\mathrm{L}_{2}^{\mathrm{h}}$. As before, let $T_{\mathrm{L} 2}^{\mathrm{hh}}=f\left(R^{\mathrm{h}}\right)$ and $T_{\mathrm{s} 2}^{\mathrm{hL}}=h\left(R^{\mathrm{b}}\right)$, with $f^{\prime}\left(R^{\mathrm{b}}\right)>0$ and $h^{\prime}\left(R^{\mathrm{h}}\right)<0$ for $R^{\mathrm{h}} \geqslant 0 .{ }^{26}$

Combining L's first-order conditions, and recalling that $f\left(R^{\mathrm{b}}\right)$ and $h\left(R^{\mathrm{h}}\right)$ are $T_{\mathrm{L} 2}^{\mathrm{hh}}$ and $T_{\mathrm{s} 2}^{\mathrm{hL}}$ respectively, a corner solution (i.e., $R^{\mathrm{h}}=0$ ) requires

$$
\begin{aligned}
{\left[1-\phi^{\mathrm{h}}(e)(1+\beta)\right] \geqslant } & \frac{V^{\prime}\left(T_{\mathrm{s}}^{\mathrm{L}}\right)}{V^{\prime}\left(T_{\mathrm{L}}^{\mathrm{h}}\right)}\left[\beta-\phi^{\mathrm{h}}(e)(1+\beta)\right]+\beta \phi^{\mathrm{h}}(e) f^{\prime}(0) \\
& +\frac{V^{\prime}\left(T_{\mathrm{s}}^{\mathrm{L}}\right)}{V^{\prime}\left(T_{\mathrm{L}}^{\mathrm{h}}\right)}\left[\beta \phi^{\mathrm{L}}(e)-\phi^{\mathrm{h}}(e)\right] h(0) .
\end{aligned}
$$

\footnotetext{
${ }^{24}$ Qualitatively similar results follow if we let $a>0$ and $b<0$. In this case, though, none of the short lived principals would prefer a long lived agent.

${ }^{25}$ Using Assumptions 1 and 2 in the appendix, it can also be shown that the second-order condition for an interior maximum is satisfied for the principals wanting a low action as well. The proof is available from the authors upon request.

${ }^{26}$ The appendix shows, in Section A.3, the precise statement of the problem and the derivation of the first-order conditions.
} 
As in the previous cases, $\phi^{\mathrm{b}}<1 / 2$ provides a sufficient condition for $R^{\mathrm{h}}$ to be positive. The proof is given in the next footnote. ${ }^{27}$ Thus, provided that the reward is positive (implying a higher level of effort implemented in period one and a lower level of effort in period two), L prefers a long lived agent. For the same reason, i.e., because the cost of implementing any action increases in the first period when a positive reward $R^{\mathrm{h}}$ is offered, $\mathrm{S}_{1}$ prefers a short lived agent so as to avoid the use of $R^{\mathrm{b}}$ by $L . S_{2}$, on the other hand, benefits from the reward since he is able to implement a lower action at a lower cost when a reward is obtained by the agent. This result is summarized in Proposition 2 below.

Proposition 2. The equilibrium to the game described in Section 2 when $L$ prefers a high outcome, $S_{1}$ and $S_{2}$ prefer a low outcome and the agents' individual rationality constraints are not binding involves a positive reward given by $L$, which in turn leaves $L$ and $S_{2}$ preferring to deal with $A_{L}$ and $S_{1}$ preferring to deal with $A_{s}$.

Summarizing the results of Propositions 1 and 2, our model predicts that when the principals' objectives are aligned, a long lived agent will be chosen. When their preferences are opposed, though, the probability of encountering a short lived agent is increased, as one of the principals alive in period one prefers to deal with this type of agent rather than with a long lived one.

\section{Binding individual rationality constraints}

In this section we briefly explore the consequences of binding individual rationality constraints for the agents.

Consider first the case when the preferences of both principals are aligned (i.e. $a>0$ ), i.e, the case meant to describe the Parliamentary system of government. Suppose that $U_{\mathrm{A} 1}^{*}$ is exactly equal to the expected utility received with the above contract (i.e., $\mathrm{IRC}_{\mathrm{A} 1}$ is just binding). The question is whether the contract of

\footnotetext{
${ }^{27}$ Let $\beta=1$. Providing a contradiction becomes more difficult now, since for $\phi^{\mathrm{h}}<1 / 2, \phi^{\mathrm{h}} f^{\prime}(0)+$ $\left[V^{\prime}\left(T_{s}^{\mathrm{L}}\right) / V^{\prime}\left(T_{\mathrm{L}}^{\mathrm{h}}\right)\right]\left(1-2 \phi^{\mathrm{h}}\right) h^{\prime}(0)$ can be either positive or negative. Nevertheless, we can show that $0>h^{\prime}\left(R^{\mathrm{h}}\right)>\left[V^{\prime}\left(T_{\mathrm{L}}^{\mathrm{b}}\right)-V^{\prime}\left(T_{\mathrm{s}}^{\mathrm{L}}\right)\right] / V^{\prime}\left(T_{\mathrm{s}}^{\mathrm{L}}\right)$ for all $R^{\mathrm{h}} \geqslant 0$. (This requires a very tedious procedure, the full derivation of which is available from the authors upon request. The steps to follow are the following: (a) Write down the expression for $\partial T_{82}^{\mathrm{hL}} / \partial R^{\mathrm{h}}=h^{\prime}\left(R^{\mathrm{b}}\right)$ from the system of equations in the appendix; (b) Compare $h^{\prime}\left(R^{\mathrm{b}}\right)$ with $\left[V^{\prime}\left(T_{\mathrm{L}}^{\mathrm{h}}\right)-V^{\prime}\left(T_{\mathrm{s}}^{\mathrm{L}}\right)\right] / V^{\prime}\left(T_{\mathrm{s}}^{\mathrm{L}}\right)$; and (c) Cancel out terms from both sides whenever possible until one side has only negative terms and the other side has only positive terms.) We need only, then, consider two extreme cases:

(i) $h^{\prime}(0)=0$. Then, the equation above reduces to the same one we found in the previous sections. Once again, a contradiction with $R^{\mathrm{h}}=0$ is obtained if $\phi^{\mathrm{h}}<1 / 2$;

(ii) $h^{\prime}(0)=\left[V^{\prime}\left(T_{\mathrm{L}}^{\mathrm{h}}\right)-V^{\prime}\left(T_{\mathrm{s}}^{\mathrm{L}}\right)\right] / V^{\prime}\left(T_{\mathrm{s}}^{\mathrm{L}}\right)$. Then, the equation above reduces to $0 \geqslant \phi^{\mathrm{h}} f^{\prime}(0)$, which is impossible for all $\phi^{\mathrm{h}}$, resulting in $\mathrm{R}^{\mathrm{h}}>0$.
} 
Section 4 will still be an equilibrium? The answer is yes, as both principals prefer a high action and therefore want the agent to participate in the game. If the individual rationality constraints were not satisfied by the contract in Section 4 , though, the new (Nash) equilibrium will require increasing the equilibrium transfers, and a solution involving zero rents for the agent will develop. Thus, when the objectives of the two principals are aligned, relaxing the assumption that the individual rationality constraints for the agents are not binding can only lead to minor changes in the equilibrium, which would now be further characterized by zero rents being captured by the agent.

Now consider $a<0$ and suppose that $\operatorname{IRC}_{\mathrm{A} 1}$ just binds when the contract offered is the one given in Section 5. It is easy to see that this contract (as long as the solution is interior) cannot be an equilibrium, since $S_{1}$ (and $S_{2}$ in period two) can withdraw his transfer to induce agent nonparticipation, the cheapest way to obtain his favorite outcome (i.e. $x=0$ ). Therefore, $L$ has to satisfy the individual rationality constraint with his offer as if $S_{1}$ and $S_{2}$ 's offers were zero. Since $S_{1}$ and $\mathrm{S}_{2}$ offer positive transfers, the agent captures rents when the principals objectives are opposed. ${ }^{28}$ Thus, an implication of our framework is that, in general, bureaucrats' rents should be higher in systems with divided government than in Parliamentary systems.

\section{Some observations on the organization of civil services}

Consider, first, the evolution of the civil service in the United States. The first movement away from patronage was the period following the Pendleton Act of $1883,{ }^{29}$ and the subsequent extension of public positions subject to the 'merit system' until the turn of the century. The second movement of civil service reform occurred during the $1920 \mathrm{~s}$ and $1930 \mathrm{~s} .{ }^{30}$ Fig. 1 summarizes this evolution. ${ }^{31}$

There are, at least, two views on the original passage of the Pendleton Act. One sees the Pendleton Act as resulting from an attempt by the Republican Party to limit the benefits the Democrats were going to enjoy from the 'spoils system' after the 1884 elections, as a Democratic victory was easily foreseeable at that time.

\footnotetext{
${ }^{28}$ This result is obtained in a more general framework by Bernhein and Whinston (1986). See Spiller (1990) for a similar treatment of the individual rationality constraints.

${ }^{29}$ The Pendleton Act was the first legal piece protecting public employees from partisan discretion, and reached, initially, about ten percent of the federal employees. See Van Ripen (1958).

${ }^{30}$ For example, the Rogers Act of 1924 extended the merit principle to the State Department, and the Hatch Act of 1939 prohibited federal employees from participating in electoral activities. See Van Ripen (1958) and Knott and Miller (1987) for a detailed discussion of the evolution of the U.S. civil service.

${ }^{31}$ Note the decline of merit appointments during the New Deal, where the Executive temporarily gained power over Congress.
} 


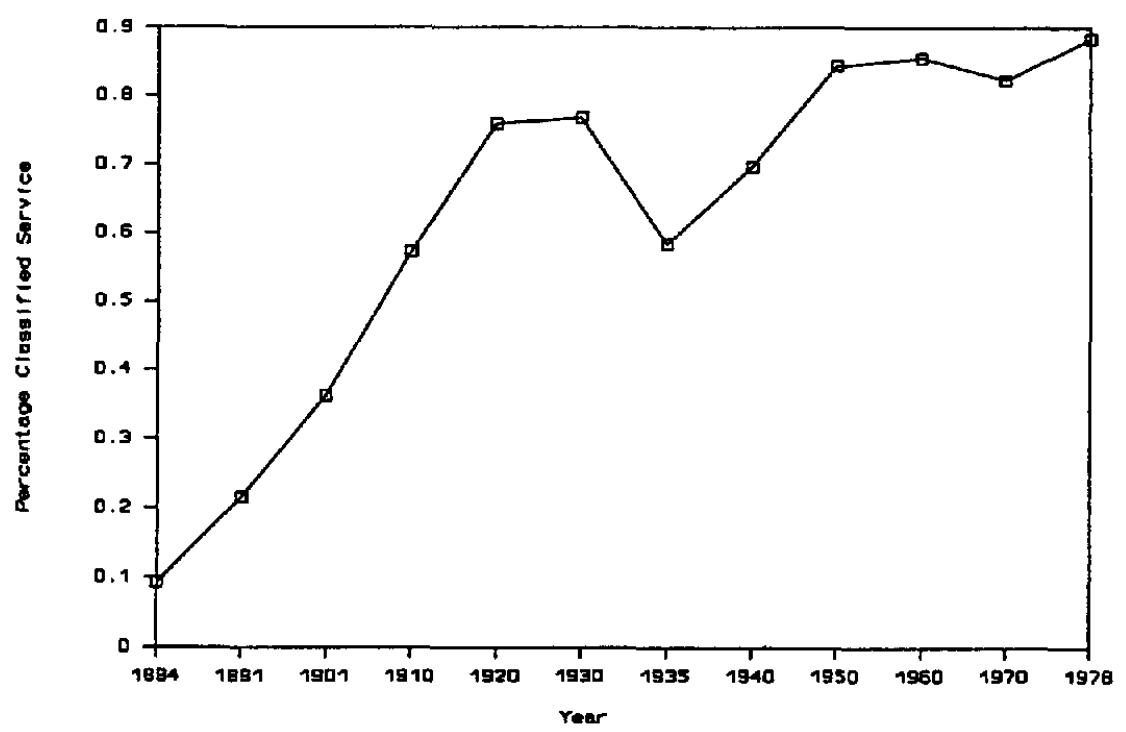

Fig. 1. Source: US Civil Service Commission (1978), and US Department of Commerce (1976).

The Democrats, it is claimed, supported the project (which they had presented a year before), because they were interested in an article limiting public employees' contributions to Republican campaigns (see, e.g. Van Ripen (1958) and Knott and Miller (1987)). The other view, recently presented by Johnson and Libecap (1990), is that the evolution of the civil service in this period obeys two factors. First, because the federal bureaucracy concerned itself mostly with postal and customs services, big users of those services exerted pressure over their legislators to pass a civil service reform so as to improve their efficiency. This issue is also recognized by Van Ripen (1958) and Knot and Miller (1987), who note the influence of the 'Progressive Reformist Movement', composed of professional middle-class taxpayers, urban merchants, rural populists and northeastern dogooders, who demanded a change towards a more efficient, nonpartisan and professional public service. Second, patronage, it is claimed, provided negative marginal benefits to the President as the latter had to devote substantial amount of time to the selection process (see Johnson and Libecap (1990)).

While both arguments may be correct, they fail to take into account that civil service legislation exists in all democracies, and that many of the civil service reforms across countries happened at similar historical times. Furthermore, since these explanations are based on particular historical accidents, they cannot account for differences across countries in the structure of civil service organizations.

Our model, while consistent with the previous theories with respect to the evolution of the U.S. merit system during last century, explains the timing of civil service reforms in the United States during this century as being the result of the 
decline in party discipline and the increase in the length in office of the US Congressmen. ${ }^{32}$

The members of Congress' declination of 'party loyalty' is a well documented stylized fact. ${ }^{33}$ For example, Knott and Miller (1987, p. 81) note, that " Party-based voting in the House, which had been at 50 percent in 1897 ... decreased during the reform era to 35 percent in 1905 and to 23 percent in 1911. Legislators found it necessary to vote with their interest group constituencies rather than with party leaders". Furthermore, they note that "ticket splitting also greatly increased. The number of counties in which the trailing Republican fell at least 5 percent behind the ticket leader increased from just over 4 percent in 1894 to just over 40 percent in 1910 '. ${ }^{34}$ As the activities of Congress started to touch individual constituencies differently, members of Congress started to bend their party loyalty, and to vote their particularistic interests.

As to the increase in the average period in office of Congressmen at the turn of the century, Fig. 2 shows that Senators' expected length in office increased rapidly during the turn of the nineteenth century and following Word War II. ${ }^{35,36}$

Until the turn of the century, then, we can see that the legislative branch was an appendix of the executive branch, and that the Congressmen that were members of the party in control of the executive branch advocated for patronage against the interests of the party with minority in Congress. Our model predicts, then, that until that time the organization of the bureaucracy should have served the interests of the executive, that is, the bureaucracy should be characterized by political appointees. While we agree that the evolution of the merit system during the first twenty years from the passage of the Pendleton Act responds to the reasons given

\footnotetext{
${ }^{32}$ Similar timing seems to explain the introduction of civil service regulations (i.e. meritocracy) in Great Britain. While patronage through the executive, with the tacit approval of the King, was the norm through the 18th century, meritocracy started to be implemented in the 1850-1860s following the Northcote-Trevelyan Report. This is precisely the time at which the Cabinet and the Parliament became more aligned. See Cox (1987, in particular p.51). See more on this below.

${ }^{33}$ Note that if this were not the case we could not really argue that Congress and the president are two different principals, for in fact the political parties could have been dictating their behavior. This is particularly the case when the party in the White House had also a majority in Congress, something quite common during the nineteenth century.

${ }^{34}$ This, however, may be the result of the introduction of the Australian ballot electoral system.

${ }^{35}$ The data on which Fig. 2 is based are constructed in the following way: (1) From the Biographical Directory of the United States Congress, we calculate the number of personnel changes in each Senate and divide that number by the number of changes due every period (one third of the members). Call that ratio the probability of losing the seat $\left(P_{\mathrm{L}}\right) ;(2)$ The expected life in office for a given period is then $6^{*}\left(1+P_{\mathrm{w}}+P_{\mathrm{w}}^{2}+\ldots\right)=6 /\left(1-P_{\mathrm{w}}\right)$, where $P_{\mathrm{w}}=1-P_{\mathrm{L}}$. (3) Taking moving averages of five previous, the current and four posterior periods, we call the resulting number 'Expected life in office'. The computation of a similar statistic for the House of Representatives would be extremely cumbersome, as the number of representatives from each state varies over time.

${ }^{36}$ Garand and Gross (1984) also note that there has been a long-term trend toward congressional safety, probably since 1894. See Kernell (1977) for a discussion of the reasons why House membership became more stable at the turn of the nineteenth century.
} 


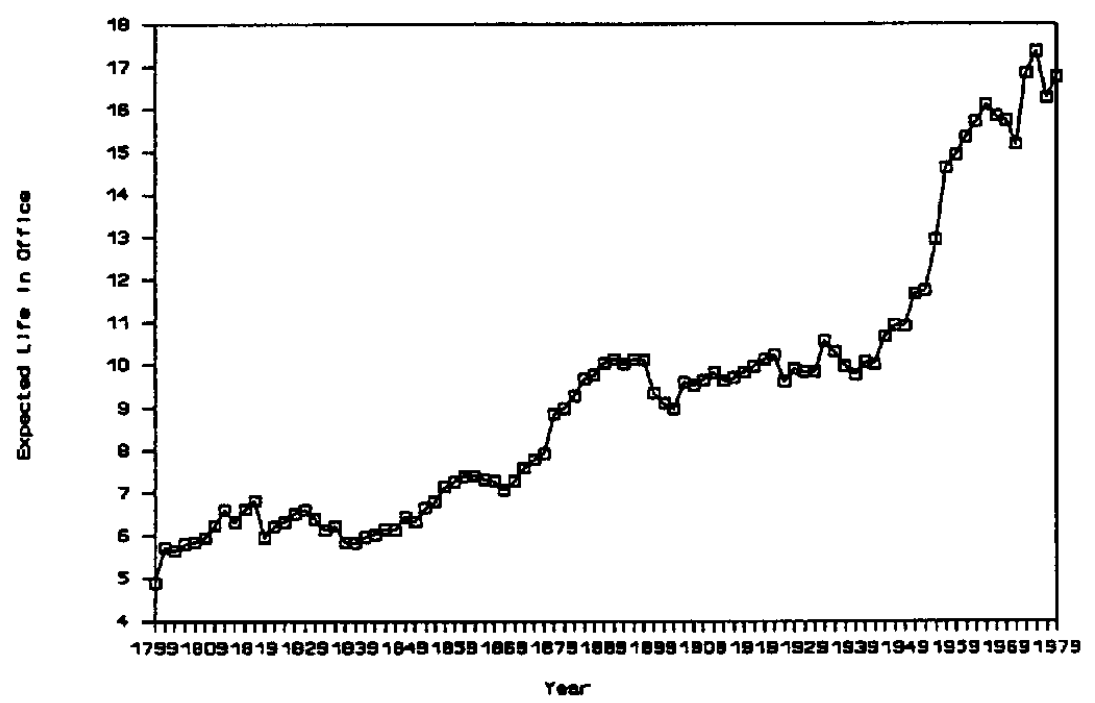

Fig. 2.

previously by other authors, we argue, though, that by the turn of the century the legislative branch became more independent from the executive, and thus it started to restrict the ability of the executive to control the bureaucracy, its instrument being the further extension of civil service reforms. ${ }^{37}$

Consider, now, the differences in the composition of the higher civil service in the United States and in the parliamentary democracies of Western Europe, in particular, Great Britain, France and West Germany. Since in parliamentary democracies the executive is composed of, and needs the support from, members of the legislative branch, our model would characterize this type of political

\footnotetext{
${ }^{37}$ Some students of the organization of the US government have raised this issue before. For example, Mainzer (1973, p.99) says "Patronage gives the chief executive a means of shaping the public service. When the governmental system itself is uncertain or threatened, as under Washington or Lincoln, patronage may be used to recruit men loyal to the regime... When merit service is routine and rigid, patronage (whether or not the appointees are party loyalists) may be used to recruit men that are vigorous, imaginative and committed to administration programs". Moe (1989) argues that interest groups influence Congressmen to limit presidential appointments in his attempts to obtain effective control of the bureaucracy. Fiorina (1986) also argues that Congressmen and bureaucrats enjoy a mutually beneficial relationship throughout time. Finally, Wilson (1989) argues that the notion that the president should administer and hold accountable to him the executive branch agencies was only established at the beginning of this century. Since the services provided at the time did not require highly specialized labor (nor did they provide substantial 'on the job learning') and congressmen remained for a short time in office, patronage produced considerably more benefits than costs to legislators. Wilson's argument,however, does not violate our model, as civil service legislation would have been the result of both congressmen's increased length in office and their reaction to limit the control of the bureaucracy by politically more powerful presidents.
} 
system as one where both the long lived principal (i.e. parliament) and the short lived principal (i.e. the prime minister and the cabinet) have similar preferences. The organization of the bureaucracy, then, should serve - as much as possible their common interests, that is, should be based on long lived bureaucrats, or civil servants. Thus, parliamentary democracies should have a lower percentage of political appointees than democratic countries based on the presidential system. ${ }^{38}$

Great Britain has had a parliamentary system of government since the end of the seventeenth century, with parliament's power becoming dominant since the middle of the eighteen century, with parliament's and the executive's objectives becoming more aligned around the $1860 \mathrm{~s}$. ${ }^{39}$ The executive power is delegated to a prime minister, who can only be installed and remain in office with the support of parliament. ${ }^{40}$

In France, during the Third and Fourth Republics, from 1875 to 1958, Prime Ministers (and the presidents in the Fourth Republic) were elected by the Assemblée Nationale (the French parliament). Also, party discipline was weak. With the Fifth Republic, and in particular since 1962, the power of the Presidency has increased. The President is currently elected directly by voters, and has received several new attributions. This shift in the allocation of power coexists, however, with the necessity to form a coalition government that is still in charge of most domestic affairs.

Finally, West Germany has gone through many different stages since 1870 . From the Bismarck to the Nazi era, the different regimes were characterized by a very strong executive. Since 1949, however, West Germany, has had a parliamentary democracy, characterized by strong legislature and a mostly ceremonial President. ${ }^{41}$

The unifying characteristic of these European countries is that during the period of formation of the current public service agencies, there was not a politically powerful institution that would, according to our model, prefer the bureaucracy to be based on political appointees. Although this situation has changed to some

\footnotetext{
${ }^{38}$ Note that according to our model this empirical implication is irrespective of which branch is formally (or informally) in control of the bureaucracy.

${ }^{39}$ Interestingly, it is in this period that major civil service reforms were introduced in Britain. Cox (1987, p. 133) notes that "the local Civil Service patronage of which the member of Parliament disposed declined throughout the nineteenth century. Positions in the revenue, postal, and other geographically dispersed branches of the Civil Service were regularly referred to the recommendation of the local member in the early part of the century. However, patronage in the revenue departments began to decline with Lord Liverpool's renunciation in 1820 of the direct appointment of superior offices in the Customs Service; and the reforms initiated by the Northcote-Trevelyan Report (1853), and furthered by Gladstone's Order in Council establishing open competition (1870), cut back the patronage throughout the Civil Service". See footnote 31.

${ }^{40}$ See Roberts and Lovecy (1984) and Deutsch et al. (1981) for a detailed analysis of the functioning of political systems in the countries discussed here.

${ }^{41}$ Interestingly, the Bundestag has a high proportion of former upper career civil servants. For instance, Roberts and Lovecy $(1984$, p. 134) report that civil servants and permanent officials of parties and interest groups comprise sixty percent of the Bundestag.
} 
extent in France, it is still the case that a parliamentary coalition is required to install a government, and hence at least the part of the executive branch dealing with domestic issues has to reflect Parliament's own preferences.

The United States, on the other hand, has had separation of powers since its creation, and as noted above, since the beginning of this century members of Congress have not only been easily reelected, but also they have had a high degree of autonomy with respect to partisan preferences. ${ }^{42}$

Given the different systems of government (and indeed of power allocation) described above, it is natural that these bureaucracies are shaped differently. According to our model, the degree of politization should be relatively higher in the U.S. and relatively lower in Great Britain, France and West Germany. Comparative studies of civil service provide support to our theory. Fesler (1983, p. 88), for example, provides evidence that the ratio of high-political to high-career officials in the US is $1: 5$, while in Great Britain and France is $1: 40$ and in Germany is $1: 80 .^{43}$ These differences, however, have been previously explained as the result of diverse traditions (the effect of the 'unwritten laws'), of different economies of scale, and of public opinion influence. ${ }^{44}$

\footnotetext{
${ }^{42}$ Furthermore, the extent of electoral split between Congress and the Executive has increased since at least the New Deal. Jacobson (1990) provides a detailed analysis of the extent of electoral split, not only between Congress and the President, but also between the House and the Senate. See also Fiorina (1990).

${ }^{43}$ With respect to the typical european agency, Fesler $(1983$, p. 90$)$ goes on to say that “...it presumably takes into account more long-range and general-interest considerations than does an American Department with its short lived political appointees". Also, Heclo (1977, p. 107) notes that, compared to the U.S., he "[does] not know of any other developed Nation in which the executive management of the govemment's senior civil service is left to the tender mercies of temporary political appointees". Furthermore, “.political appointees are simply uninterested. Effective management of the higher civil service is of immense long-term importance. But nothing will have very much effect during an appointee's own short time in office. Most appointees behave exactly as you and I would if faced with the same incentives: they exploit careerists and do little to build career institutions."

${ }^{44}$ For example, reviewing the possible determining factors that influence the different shape of higher civil services, Stanley (1983, p. 93) notes that "Great Britain, Canada, France, Germany, and the United States differ in political history, structure, and culture. All but the United States have a parliamentary form of government, with its intertwining of legislative and executive work. Three of the five countries are federal; two are unitary. Transitions among the ruling parties vary in their frequency and in their effects on the different bureaucracies, as does the degree of popular and political regard for the public service... Finally, the bureaucracies themselves differ from one country to another in their composition (social, ethnic, educational), in their traditional behavior and attitudes, and in their political strength". Pfiffner (1987), on the other hand, while in principle focusing the attention on the same issues as we do here, i.e. the separation of powers, conjectures that lack of party control over both branches of government implies that the civil service will have a higher percentage of political appointees. Wilson's (1989) explanation overlaps with ours, as it stresses the importance of different political systems, although it overlooks the relevance of different time horizons. In addressing the question of different use of political appointments between Great Britain and the United States, Wilson (1989, pp. 257-258) argues that "In a word, the answer is the Constitution. That document makes the president and Congress rivals for control of the American administrative system... In Great Britain, the prime minister and parliament are not rivals because the House of Commons has no significant power to supervise, investigate, intervene in, or even obtain answers from the bureaucracy."
} 
Finally, consider the differences in the organization of the civil services in the United States at the local level of government. The main feature to explain is the differential use of merit systems across cities. ${ }^{45}$ When the mayor is elected directly by voters the local form of government resembles the presidential system with separation of powers, since there is no need for the mayor and the council to share the same policy goals. ${ }^{46}$ If elected indirectly, the mayor responds to the council and therefore there is no real separation of powers, the local analog to parliamentary systems. We find, as predicted by our model, that, even considering regional differences, there is a negative correlation between complete adoption of merit systems and mayors being elected directly across cities over 25,000 inhabitants. In Table 1, we estimate the determinants of complete adoption of civil service legislation. We use as explanatory variables the form of government, population and the regional location of the cities. The estimated coefficient of the form of government is negative and significant, providing some support to our theory. At the mean values of the explanatory variables, a change towards directly elected mayor without a chief administrative officer (CAO) decreases the probability of complete adoption of merit systems by twenty percentage points. ${ }^{47}$

\footnotetext{
${ }^{45}$ Although studies of the different systems of local government in the U.S. usually focus on whether those are mayor-council or council-manager ones (where the latter system avoids the separation of powers) we prefer to consider whether the mayor (without a chief administrative officer - CAO - who is a professional administrator responsible for the daily management of the city, and whose nomination sometimes requires council approval) is elected directly by voters or not (in which case the Mayor is generally selected by the council among its members) as the real measure of whether there is separation of powers or not. Since almost all the cities with mayor without CAO (MWCAO) (78 out of 79 in our sample) have direct elections, the results reported below remain almost intact when we just consider all cities with MWCAO governments.

${ }^{46}$ This is especially true for mayors without CAOs, as these are professional. Adrian (1988, p. 9), for example, notes that "With the success and continuing expansion of the office of CAO and the ever-wider use of the merit system, differences in professionalism between the two forms continue to diminish".

${ }^{47}$ There is at least another feature that can be explained by our model, named that the proportion of political appointees is a negative function of the population of the city. For example, Stahl (1971) reports that "all cities of 250,000 or over (inhabitants), except one, have total or almost total merit-system coverage for their civil services... Among cities with 50,000 to 250,000 population, only about 12 percent are without merit systems... About 22 percent of those in the 25,000 to 50,000 class are so handicapped". There are two feasible reasons for this correlation. First, excluding the five largest cities in the US, the probability of a direct system of election for the mayor without CAO, i.e., the local parallel of presidential systems, decreases with city size. This is supported by the following estimated probit model

$$
\begin{aligned}
& \text { Prob }(\text { MDEWCAO }=1)=\Phi\left(-0.68-0.00504 \text { Pop }+0.0000074 \text { Pop }^{2}\right) \\
& \text { ( } t \text {-stat) } \quad(-5.23)(-2.76)
\end{aligned}
$$

Log-likelihood $=-192.64$, \% right predictions $=83,437$ observations,

with the critical value of population at which its effect becomes positive being 340.540 , well above the mean size in the sample (94 percent of the cities are below this value). Second, the average length in office for councilmen increases with city size: 50 percent of the council members of cities over 500,000 inhabitants remain in office five years or more; for cities in the range $250,000-500,000,100,000$ $250,000,25,000-100,000$, the corresponding percentages are 48,40 and 38 percent respectively. (Source: Municipal Year Book, 1972.) Our model, then, would suggest that Civil Service provisions should be more prevalent in larger cities, as seems to be the case according to Stahl.
} 
Table 1

Estimation results a,b

\begin{tabular}{lccc}
\hline $\begin{array}{l}\text { Independent } \\
\text { (T-statistic) }\end{array}$ & Dependent & & CS \\
\cline { 2 - 4 } & CS & -0.219 & 0.026 \\
\hline Constant & -0.228 & $(-2.13)$ & $(-0.20)$ \\
MDEWCAO & $(-2.84)$ & -0.438 & -0.514 \\
& -0.436 & $(-2.60)$ & $(-2.92)$ \\
Population & $(-2.59)$ & 0.00124 & 0.0015 \\
(thousands) & 0.00139 & $(1.12)$ & $(3.16)$ \\
Pop. squared & $(3.01)$ & $2.08 \mathrm{E}-7$ & \\
& & $(0.14)$ & -0.887 \\
South & & & $(-4.72)$ \\
& & & -0.313 \\
Midwest & & & $(-1.96)$ \\
& & & 0.37 \\
West & & 58 & $(1.98)$ \\
& & 442 & -270.22 \\
Log-likelihood & & & 66 \\
\% right predictions & 57 & 442 \\
No. of observations & 442 & & \\
\hline
\end{tabular}

\footnotetext{
Method: Probit. Year 1963.

${ }^{b}$ Variables: CS (Civil Service) $=1$ if all employees are covered by civil service legislation, 0 otherwise; MDEWCAO (mayors directly elected without $\mathrm{CAO}$ ) $=1$ if the city has this type of government, 0 otherwise; South (includes Alabama, Arkansas, Florida, Georgia, Louisiana, Mississippi, North Carolina, South Carolina, Texas and Virginia) $=1$ if the cities belongs to the region, 0 otherwise; Midwest (Illinois, Indiana, Michigan, Ohio, Wisconsin, Iowa, Kansas, Minnesota, Missouri, Nebraska, North Dakota and South Dakota) $=1$ if the city belongs to the region, 0 otherwise; and West (Colorado, Idaho, Montana, Nevada, Utah, Wyoming, California, Oregon and Washington) $=1$ if the city belongs to the region, 0 otherwise.
}

Source: Municipal Year Book, 1963, 1972 and 1976. The 1963 Municipal Year Book is the most recent to classify cities over 25,000 inhabitants according to complete, partial and nil scope of civil service coverage of municipal employees (there are 611 observations of cities); the 1972 issue has the nearest (in time) series of city governments discriminating by election system and existence of CAO, so it is used (except for a few cities in which the statistic is lacking, in which cases it is completed with observations of the 1976 issue) whenever possible, resulting in 442 observations (169 were lost).

To summarize, a framework that sees in civil service regulations ways to restrict the ability of the executive to control the bureaucracy is consistent with some stylized facts of the organization of civil services across countries, local governments and over time in the U.S. (once again, during this century).

The model that we develop below is rooted in the transaction cost/agency approach to institutions, where the nature of organizations is the result of the need 
to control. Our framework combines institutional features, like separation of powers and the need to delegate, with the modern theory of common agency in a multiperiod setup. ${ }^{48}$ The organization of political bureaucracies, however, will differ depending on the characteristics of the principals the bureaucracy is supposed to serve.

\section{Conclusions}

This paper presents a model that can be used to explain the evolution of the U.S. Federal Civil Service during this century, the relatively high number of political appointees in the U.S. compared with other western democracies, and the different proportion of political appointees in different U.S. cities. The key factors are the separation of legislative and executive powers, the effective residence of that power, the expected life in office for Congressmen, and party discipline.

We argue that during the nineteenth century members of Congress remained in office for short periods of time, and party discipline was strong, with the party represented in the executive usually being the majority party in Congress. This being the case, neither of the two principals competing for public service positions were particularly interested in long term agents. As a result, the number of political appointees was relatively high.

On the other hand, the twentieth century witnessed the decline of party discipline and the increase in the length in office of Congressmen. Thus, the composition of the civil service's labor force can be understood as the outcome of a game played by one short and one long lived principals (the president and Congress respectively), which in turn lead to the extension of civil service legislation over this century. Finally, our model predicts that the stronger Congress is (or alternatively, the more aligned Congress and the Executive are), the fewer political appointees will be in the civil service, a characteristic observed across countries and U.S. cities as well.

\section{Appendix}

In what follows we make the following assumptions:

Assumption 1. $\phi^{\mathrm{h}^{\prime}}(e) / \phi^{\mathrm{L}}(e)$, i.e., the hazard rate, increases with $e$, i.e., $-\phi^{\mathrm{h}^{\prime \prime}}(e) \phi^{\mathrm{L}}(e)<\phi^{\mathrm{h}^{\prime}}(e)^{2} .{ }^{49}$

\footnotetext{
${ }^{48}$ For models of common agency, see Bernhein and Whinston (1986). See also Spiller (1990) and Laffont and Tirole (1988) for applications. For agency models with multiple periods, see Radner (1985) and Rubinstein and Yaari (1983).

${ }^{49}$ This assumption is standard in the information literature. It basically says that given that a high outcome has not occurred, increasing effort makes its appearance each time more likely. It is respected by many distributions, in particular by $\phi^{\mathrm{h}}(e)=2-e^{-1}(e \in(1 / 2,1))$.
} 
Assumption 2. $-\phi^{\mathrm{h}^{\mathrm{h}}}(e) / \phi^{\mathrm{h}^{\prime}}(e)$ decreases with $e$, but not 'too fast', i.e., $2 \geqslant\left(\phi^{\mathrm{b}^{\prime}}(e) \phi^{\mathrm{h}^{\mathrm{m}}}(e) / \phi^{\mathrm{h}^{\prime \prime}}(e)^{2}\right) \geqslant 1$. $^{50}$

Assumption 3. $\quad V($.$) displays nonincreasing aversion towards risk, i.e.,$

$$
[V(T+R)-V(R)] V^{\prime \prime}(T+R) \geqslant\left[V^{\prime}(T+R)-V^{\prime}(R)\right] V^{\prime}(T+R)
$$

and

$$
[V(T+R)-V(R)] V^{\prime \prime}(R) \leqslant\left[V^{\prime}(T+R)-V^{\prime}(R)\right] V^{\prime}(R) .
$$

\section{A.1. Equilibrium in period 2: One principal-one agent} by $^{51}$

We now start with the problem of the single principal. The problem is given

$$
\begin{aligned}
\max Z= & \left\{\phi^{\mathrm{L}}\left(e_{1}\right)\left[b x_{1}^{\mathrm{L}}+\phi^{\mathrm{L}}\left(e_{2}^{\mathrm{L}}\right) b x_{2}^{\mathrm{L}}+\phi^{\mathrm{h}}\left(e_{2}^{\mathrm{L}}\right)\left(b x_{2}^{\mathrm{h}}-T_{2}^{\mathrm{Lh}}\right)\right]\right. \\
& +\phi^{\mathrm{h}}\left(e_{1}\right)\left[b x_{1}^{\mathrm{h}}-T_{1}^{\mathrm{h}}-R^{\mathrm{h}}+\phi^{\mathrm{L}}\left(e_{2}^{\mathrm{h}}\right) b x_{2}^{\mathrm{L}}+\phi^{\mathrm{h}}\left(e_{2}^{\mathrm{h}}\right)\left(b x_{2}^{\mathrm{h}}-T_{2}^{\mathrm{h}}\right)\right\} \\
& +\lambda_{1}\left\{\phi^{\mathrm{h}^{\prime}}\left(e_{1}\right)\left[V\left(T_{1}^{\mathrm{h}}\right)+\beta \Delta E U_{\mathrm{A} 2}^{\mathrm{h}}\left(R^{\mathrm{h}}\right)\right]-1\right\} \\
& +\phi^{\mathrm{L}}\left(e_{1}\right) \lambda_{2}^{\mathrm{L}}\left\{\phi^{\mathrm{h}^{\prime}}\left(e_{2}^{\mathrm{L}}\right) V\left(T_{2}^{\mathrm{Lh}}\right)-1\right\} \\
& +\phi^{\mathrm{h}}\left(e_{1}\right) \lambda_{2}^{\mathrm{h}}\left\{\phi^{\mathrm{h}^{\prime}}\left(e_{2}^{\mathrm{h}}\right)\left[V\left(T_{2}^{\mathrm{hh}}+R^{\mathrm{h}}\right)-V\left(R^{\mathrm{h}}\right)\right]-1\right\},
\end{aligned}
$$

with respect to $e_{1}, T_{1}^{\mathrm{h}}, R^{\mathrm{h}}, \lambda_{1}, e_{2}^{j}, T_{2}^{j h}$ and $\lambda_{2}^{j}$ for $j=\mathrm{h}, \mathrm{L}$. We solve the problem backwards. The system of first-order conditions for $P_{2}^{\mathrm{h}}$ is given in the main part of the paper. Totally differentiating that system, and after replacing $\left[b\left(x_{2}^{\mathrm{h}}-x_{2}^{\mathrm{L}}\right)-T_{2}^{\mathrm{h}}\right]$ and $\lambda_{2}^{\mathrm{h}}$ from these first-order conditions we have ${ }^{52}$

$$
\begin{aligned}
& {\left[-\frac{\phi^{\mathrm{h}^{\prime \prime 2}} \phi^{\mathrm{h}} \Delta V}{\phi^{\mathrm{h}^{\mathrm{h}^{2}}} V^{\prime}}+\frac{\phi^{\mathrm{h}} \phi^{\mathrm{h}^{\prime \prime \prime}} \Delta V}{\phi^{\mathrm{h}^{\prime}} V^{\prime}}\right] \mathrm{d} e_{2}^{\mathrm{h}}+\left[-\phi^{\mathrm{h}^{\prime}}+\frac{\phi^{\mathrm{h}} \phi^{\mathrm{h}^{\prime \prime}}}{\phi^{\mathrm{h}^{\prime}}}\right] \mathrm{d} T_{2}^{\mathrm{hh}}} \\
& +\phi^{\mathrm{h}^{\prime \prime}} V \mathrm{~d} \lambda_{2}^{\mathrm{h}}=-\frac{\phi^{\mathrm{h}} \phi^{\mathrm{h}^{\prime \prime}}}{\phi^{\mathrm{h}^{\prime}} V^{\prime}} \Delta V^{\prime} \mathrm{d} R^{\mathrm{h}},
\end{aligned}
$$

\footnotetext{
${ }^{50}$ This assumption is satisfied by the density function referred to in the previous footnote.

${ }^{51}$ Note that we already set transfers and reward equal to zero when the outcome is low, that is, $R^{\mathrm{L}}=T_{1}^{\mathrm{L}}=T_{2}^{\mathrm{L}}=0$. Also, note the use of the first-order approach to the principal-agent problem.

${ }^{52}$ For ease of notation we suppress the arguments $e_{2}^{\mathrm{h}}$ from $\phi^{\mathrm{h}}(e), \phi^{\mathrm{h}^{\prime}}\left(e_{2}^{\mathrm{h}}\right), \phi^{\mathrm{h}^{\prime \prime}}\left(e_{2}^{\mathrm{h}}\right)$, and $\phi^{\mathrm{h}^{\prime \prime}}\left(e_{2}^{\mathrm{h}}\right)$. Similarly, $\quad V^{\prime}=V^{\prime}\left(T_{2}^{\text {hh }}+R^{\mathrm{h}}\right), \quad V^{\prime \prime}=" V\left(T_{2}^{\text {hh }}+R^{\mathrm{b}}\right), \quad \Delta V=\left[V\left(T_{2}^{\text {hh }}+R\right)-V(R)\right]>0$ and $\Delta V^{\prime}=$ $\left[V^{\prime}\left(T_{2}^{\text {bh }}+R\right)-V^{\prime}(R)\right]<0$.
} 


$$
\left[-\phi^{\mathrm{h}^{\prime}}+\frac{\phi^{\mathrm{h}} \phi^{\mathrm{h}^{\prime \prime}}}{\phi^{\mathrm{h}^{\prime}}}\right] \mathrm{d} e_{2}^{\mathrm{h}}+\frac{\phi^{\mathrm{h}} V^{\prime \prime}}{V^{\prime}} \mathrm{d} T_{2}^{\mathrm{hh}}+\phi^{\mathrm{h}^{\prime}} V^{\prime} \mathrm{d} \lambda_{2}^{\mathrm{h}}=-\frac{\phi^{\mathrm{h}} V^{\prime \prime}}{V^{\prime}} \mathrm{d} R^{\mathrm{h}},
$$

$\phi^{\mathrm{h}^{\prime \prime}} V \mathrm{~d} e_{2}^{\mathrm{h}}+\phi^{\mathrm{h}^{\prime}} V^{\prime} \mathrm{d} T_{2}^{\mathrm{hh}}=-\phi^{\mathrm{h}} \Delta V^{\prime} \mathrm{d} R^{\mathrm{h}}$.

The determinant $(\Delta)$ of the system above reduces to

$$
\Delta=\phi^{\mathrm{h}} \Delta V V^{\prime}\left(3 \phi^{\mathrm{h}^{\prime \prime 2}}-\phi^{\mathrm{h}^{\prime}} \phi^{\mathrm{h}^{\prime \prime}}\right)-2 \phi^{\mathrm{h}^{\prime \prime} \mathrm{h}^{\mathrm{h}^{2}} \Delta V V^{\prime}}-\frac{\phi^{\mathrm{h}^{\prime 2}} \phi^{\mathrm{h}} \Delta V^{2} V^{\prime \prime}}{V^{\prime}},
$$

which is positive by Assumption 2. Also, using Cramer's Rule, we obtain

$$
\begin{aligned}
\frac{\mathrm{d} e_{2}^{\mathrm{h}}}{\mathrm{d} R^{\mathrm{h}}}= & \frac{-\phi^{\mathrm{h}} \phi^{\mathrm{h}^{\prime}} \phi^{\mathrm{h}^{\prime \prime}} \Delta V^{\prime}\left(R^{\mathrm{h}}\right) V^{\prime \prime}\left(T_{2}^{\mathrm{hh}}+R^{\mathrm{h}}\right)}{V^{\prime}\left(T_{2}^{\mathrm{hh}}+R^{\mathrm{h}}\right)}+\phi^{\mathrm{h}} \Delta V^{\prime} V^{\prime}\left(T_{2}^{\mathrm{hh}}+R^{\mathrm{h}}\right) \\
\frac{\mathrm{d} T_{2}^{\mathrm{hh}}}{\mathrm{d} R^{\mathrm{h}}}= & \left\{\phi^{\mathrm{h}^{\prime 2}} \phi^{\mathrm{h}^{\prime \prime}} \Delta V \Delta V^{\prime}+\frac{\phi^{\mathrm{h}^{\mathrm{n} 2}} \phi^{\mathrm{h}} \Delta V}{V}\left[\Delta V V^{\prime \prime}-\Delta V^{\prime} V^{\prime}\right]\right. \\
& \left.+\Delta V \Delta V^{\prime} \phi^{\mathrm{h}}\left(\phi^{\mathrm{h}^{\prime}} \phi^{\mathrm{h}^{\prime \prime \prime}}-2 \phi^{\mathrm{h}^{n^{2}}}\right)\right\}(\Delta\}^{-1}>0,
\end{aligned}
$$

where the last sign results from Assumptions 2 and 3.

Once the responses in the second period have been determined, the problem in period one can be written as

$$
\begin{aligned}
\max Z= & \left\{\phi^{\mathrm{L}}\left(e_{1}\right)\left[b x_{1}^{\mathrm{L}}+\phi^{\mathrm{L}}\left(e_{2}^{\mathrm{L}}\right) b x_{2}+\phi^{\mathrm{h}}\left(e_{2}^{\mathrm{L}}\right)\left(b x_{2}^{\mathrm{h}}-T_{2}^{\mathrm{Lh}}\right)\right]\right. \\
& +\phi^{\mathrm{h}}\left(e_{1}\right)\left[b x_{1}^{\mathrm{h}}-T_{1}^{\mathrm{h}}-R^{\mathrm{h}}+\phi^{\mathrm{L}}\left(g\left(R^{\mathrm{h}}\right)\right) b x_{2}^{\mathrm{L}}\right. \\
& \left.+\phi^{\mathrm{h}}\left(g\left(R^{\mathrm{h}}\right)\right)\left(b x_{2}^{\mathrm{h}}-f\left(R^{\mathrm{h}}\right)\right]\right\} \\
& +\lambda_{1}\left\{\phi^{\mathrm{h}^{\prime}}\left(e_{1}\right)\left[V\left(T_{1}^{\mathrm{h}}\right)+\beta \Delta \mathrm{E} U_{\mathrm{A}_{2}}^{\mathrm{h}}\left(R^{\mathrm{h}}\right)\right]-1\right\} \\
& +\phi^{\mathrm{L}}\left(e_{1}\right) \lambda_{2}^{\mathrm{L}}\left\{\phi^{\mathrm{h}^{\prime}}\left(e_{2}^{\mathrm{L}}\right) V\left(T_{2}^{\mathrm{Lh}}\right)-1\right\} \\
& +\phi^{\mathrm{h}}\left(e_{1}\right) \lambda_{2}^{\mathrm{h}}\left\{\phi^{\mathrm{h}^{\prime}}\left(g\left(R^{\mathrm{h}}\right)\right)\left[V\left(f\left(R^{\mathrm{h}}\right)+R^{\mathrm{h}}\right)-V\left(R^{\mathrm{h}}\right)\right]-1\right\},
\end{aligned}
$$

with respect to $e_{1}, T, R^{\mathrm{h}}$ and $\lambda_{1}$, where

$$
\begin{aligned}
\Delta \mathrm{E} U_{\mathrm{A} 2}^{\mathrm{h}}\left(R^{\mathrm{h}}\right)= & \phi^{\mathrm{L}}\left(g\left(R^{\mathrm{h}}\right)\right) V\left(R^{\mathrm{h}}\right)+\phi^{\mathrm{h}}\left(g\left(R^{\mathrm{h}}\right)\right) V\left(f\left(R^{\mathrm{h}}\right)+R^{\mathrm{h}}\right) \\
& -\phi^{\mathrm{h}}\left(e_{2}^{\mathrm{L}}\right) V\left(T_{\mathrm{L} 2}^{\mathrm{Lh}}\right)-\left(e_{2}^{\mathrm{h}}-e_{2}^{\mathrm{L}}\right) \geqslant 0 .
\end{aligned}
$$

Thus, differentiation with respect to $e_{1}, T_{1}^{\mathrm{h}}, R^{\mathrm{h}}$ and $\lambda_{1}$ results in

$$
\begin{gathered}
e_{1}: \phi^{\mathrm{h}^{\prime}}\left(e_{1}\right)\left\{\left[b\left(x_{1}^{\mathrm{h}}-x_{1}^{\mathrm{L}}\right)-T_{1}^{\mathrm{h}}-R^{\mathrm{h}}\right]+\left(\mathrm{E} U_{P 2}^{\mathrm{h}}-\mathrm{E} U_{\mathrm{P} 2}^{\mathrm{L}}\right)\right\} \\
+\lambda_{1} \phi^{\mathrm{h}^{\prime \prime}}\left(e_{1}\right)\left[V\left(T_{1}^{\mathrm{h}}\right)+\beta \Delta \mathrm{E} U_{\mathrm{A} 2}^{\mathrm{h}}\left(R^{\mathrm{h}}\right)\right]=0 .
\end{gathered}
$$




$$
\begin{aligned}
& T_{1}^{\mathrm{h}}:- \phi^{\mathrm{h}}\left(e_{1}\right)+\lambda_{1} \phi^{\mathrm{h}^{\prime}}\left(e_{1}\right) V^{\prime}\left(T_{1}^{\mathrm{h}}\right)=0, \\
& R^{\mathrm{h}}:- \phi^{\mathrm{h}}\left(e_{1}\right)\left[1-\phi^{\mathrm{h}^{\prime}}\left(e_{2}^{\mathrm{h}}\right)\left[b\left(x_{2}^{\mathrm{h}}-x_{2}^{\mathrm{L}}\right)-T_{2}^{\mathrm{hh}}\right] g^{\prime}\left(R^{\mathrm{h}}\right)+\phi^{\mathrm{h}}\left(e_{2}^{\mathrm{h}}\right) f^{\prime}\left(R^{\mathrm{h}}\right)\right] \\
&+\lambda_{1} \beta \phi^{\mathrm{h}^{\prime}}\left(e_{1}\right)\left\{\phi^{\mathrm{L}}\left(e_{2}^{\mathrm{h}}\right) V^{\prime}\left(R^{\mathrm{h}}\right)+\phi^{\mathrm{h}}\left(e_{2}^{\mathrm{h}}\right) V^{\prime}\left(T_{2}^{\mathrm{hh}}+R^{\mathrm{h}}\right)\right. \\
&\left.+\phi^{\mathrm{h}}\left(e_{2}^{\mathrm{h}}\right) V^{\prime}\left(T_{2}^{\mathrm{hh}}+R^{\mathrm{h}}\right) f^{\prime}\left(R^{\mathrm{h}}\right)\right\}+\lambda_{2}^{\mathrm{h}} \phi^{\mathrm{h}}\left(e_{1}\right) \\
& \times\left\{\phi^{\mathrm{h}^{\prime}}\left(e_{2}^{\mathrm{h}}\right)\left[V^{\prime}\left(T_{2}^{\mathrm{h}}+R^{\mathrm{h}}\right)-V^{\prime}\left(R^{\mathrm{h}}\right)\right]+\phi^{\mathrm{h}^{\prime}}\left(e_{2}^{\mathrm{h}}\right) V^{\prime}\left(T_{2}^{\mathrm{hh}}+R^{\mathrm{h}}\right)\right. \\
&\left.\times f^{\prime}\left(R^{\mathrm{h}}\right)+\phi^{\mathrm{h}^{\prime \prime}}\left(e_{2}^{\mathrm{h}}\right)\left[V\left(T_{2}^{\mathrm{hh}}+R^{\mathrm{h}}\right)-V\left(R^{\mathrm{b}}\right)\right] g^{\prime}\left(R^{\mathrm{b}}\right)\right\}=0, \\
& \lambda_{1}: \phi^{\mathrm{h}^{\prime}}\left(e_{1}\right)\left[V\left(T_{1}^{\mathrm{h}}\right)+\beta \Delta \mathrm{E} U_{\mathrm{A} 2}^{\mathrm{h}}\left(R^{\mathrm{h}}\right)\right]-1=0,
\end{aligned}
$$

where $\left\{\left[b\left(x_{1}^{\mathrm{h}}-x_{1}^{\mathrm{h}}\right)-T_{1}^{\mathrm{h}}-R^{\mathrm{h}}\right]+\left(E U_{\mathrm{P} 2}^{\mathrm{h}}-\mathrm{E} U_{\mathrm{P} 2}^{\mathrm{L}}\right)\right\}$ is assumed to be strictly positive (i.e., the principal prefers a high outcome even net of transfers).

\section{A.2. Equilibrium in period two with two principals: Aligned interests}

Totally differentiating Eqs. (7), (8) and (9), and after replacing $\left[b\left(x_{2}^{\mathrm{h}}-x_{2}^{\mathrm{L}}\right)-\right.$ $\left.T_{\mathrm{L} 2}^{\mathrm{hh}}\right]$ and $\left[a\left(x_{2}^{\mathrm{h}}-x_{2}^{\mathrm{L}}\right)-T_{\mathrm{s} 2}^{\mathrm{hh}}\right]$ from the $L_{2}^{\mathrm{h}}$ and $S_{2}^{\mathrm{h}}$ 's first-order conditions we obtain the following system:

$$
\begin{gathered}
{\left[-\phi^{\mathrm{h}^{\prime}}+\frac{\phi^{\mathrm{h}} \phi^{\mathrm{h}^{\prime \prime}}}{\phi^{\mathrm{h}^{\prime}}}\left(2-\frac{\phi^{\mathrm{h}^{\prime}} \phi^{\mathrm{h}^{\prime \prime}}}{\phi^{\mathrm{h}^{\prime 2}}}\right)\right] \mathrm{d} e_{2}^{\mathrm{h}}+\left[\frac{\phi^{\mathrm{h}^{\prime 2}} V^{\prime}}{\phi^{\mathrm{h}^{\prime \prime}} \Delta V}-\frac{\phi^{\mathrm{h}} V^{\prime}}{\Delta V}+\frac{\phi^{\mathrm{h}} V^{\prime \prime}}{V^{\prime}}\right] \mathrm{d} T_{\mathrm{L} 2}^{\mathrm{hh}}} \\
+\phi^{\mathrm{h}}\left[\frac{V^{\prime}}{\Delta V}-\frac{V^{\prime \prime}}{V^{\prime}}\right] \mathrm{d} T_{\mathrm{s} 2}^{\mathrm{hh}}=\frac{\Delta V^{\prime} V^{\prime}-\Delta V V^{\prime \prime}}{\phi^{\mathrm{h}-1} \Delta V V^{\prime}} \mathrm{d} R^{\mathrm{h}}, \\
{\left[-\phi^{\mathrm{h}^{\prime}}+\frac{\phi^{\mathrm{h}} \phi^{\mathrm{h}^{\prime \prime}}}{\phi^{\mathrm{h}^{\prime}}}\left(2-\frac{\phi^{\mathrm{h}^{\prime}} \mathrm{h}^{\mathrm{h}^{\prime \prime \prime}}}{\phi^{\mathrm{h}^{\prime 2}}}\right)\right] \mathrm{d} e_{2}^{\mathrm{h}}-\phi^{\mathrm{h}}\left[\frac{V^{\prime \prime}}{V^{\prime}}-\frac{V^{\prime}}{\Delta V}\right] \mathrm{d} T_{\mathrm{L} 2}^{\mathrm{hh}}} \\
+\left[\frac{\phi^{\mathrm{h}^{\prime 2}} V^{\prime}}{\phi^{\mathrm{h}^{\prime \prime}} V}-\frac{\phi^{\mathrm{h}} V^{\prime}}{\Delta V}+\frac{\phi^{\mathrm{h}} V^{\prime \prime}}{V^{\prime}}\right] \mathrm{d} T_{\mathrm{s} 2}^{\mathrm{hh}}=\frac{\Delta V^{\prime} V^{\prime}-\Delta V V^{\prime \prime}}{\phi^{\mathrm{h}-1} \Delta V V^{\prime}} \mathrm{d} R^{\mathrm{h}},
\end{gathered}
$$

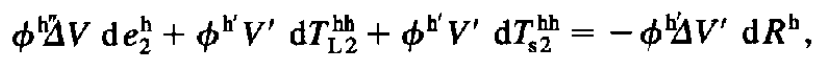

where $\Delta V=\left[V\left(T_{\mathrm{L} 2}^{\mathrm{hh}}+T_{\mathrm{s} 2}^{\mathrm{hh}}+R^{\mathrm{h}}\right)-V\left(R^{\mathrm{h}}\right)\right]>0, \quad \Delta V^{\prime}=\left[V^{\prime}\left(T_{\mathrm{L} 2}^{\mathrm{hh}}+T_{\mathrm{s} 2}^{\mathrm{hh}}+R^{\mathrm{h}}\right)-\right.$ $\left.V^{\prime}\left(R^{\mathrm{h}}\right)\right]<0$, and $V^{\prime}=V^{\prime}\left(T_{\mathrm{L} 2}^{\mathrm{hh}}+T_{\mathrm{s} 2}^{\mathrm{hh}}+R^{\mathrm{h}}\right)$. Noting that the first term on the right-hand side of the first two equations is negative from Assumptions 1 and 2 , it is easy to check that the determinant is negative. Also, $\partial e_{2}^{\mathrm{h}} / \partial R^{\mathrm{h}}<0$ and $\partial T_{\mathrm{L} 2}^{\mathrm{hh}} / \partial R^{\mathrm{h}}$ $=\partial T_{\mathrm{s} 2}^{\mathrm{hh}} / \partial R^{\mathrm{h}}>0$ follow immediately.

Finally, the long lived principal's problem in period one can be written as

$$
\begin{aligned}
& \max Z=\left\{\phi^{\mathrm{L}}\left(e_{1}\right)\left[b x_{1}^{\mathrm{L}}+\phi^{\mathrm{L}}\left(e_{2}^{\mathrm{L}}\right) b x_{2}^{\mathrm{L}}+\phi^{\mathrm{h}}\left(e_{2}^{\mathrm{L}}\right)\left(b x_{2}^{\mathrm{h}}-T_{\mathrm{L} 2}^{\mathrm{Lh}}\right)\right]\right. \\
&+\phi^{\mathrm{h}}\left(e_{1}\right)\left[b x_{1}^{\mathrm{h}}-T_{\mathrm{L} 1}^{\mathrm{h}}-R^{\mathrm{h}}+\phi^{\mathrm{L}}\left(e_{2}^{\mathrm{h}}\right) b x_{2}^{\mathrm{L}}\right.
\end{aligned}
$$




$$
\begin{aligned}
& \left.+\phi^{\mathrm{h}}\left(e_{2}^{\mathrm{h}}\right)\left(b x_{2}^{\mathrm{h}}-f\left(R^{\mathrm{h}}\right)\right]\right\} \\
& +\lambda_{\mathrm{L} 1}\left\{\phi^{\mathrm{h}^{\prime}}\left(e_{1}\right)\left[V\left(T_{\mathrm{L} 1}^{\mathrm{h}}+T_{\mathrm{s} 1}^{\mathrm{h}}\right)+\beta \Delta \mathrm{E} U_{\mathrm{A} 2}^{\mathrm{h}}\left(R^{\mathrm{h}}\right)\right]-1\right\} \\
& +\phi^{\mathrm{L}}\left(e_{1}\right) \lambda_{\mathrm{L} 2}^{\mathrm{L}}\left\{\phi^{\mathrm{h}^{\prime}}\left(e_{2}^{\mathrm{L}}\right)\left[V\left(T_{\mathrm{L} 2}^{\mathrm{Lh}}+T_{\mathrm{s} 2}^{\mathrm{Lh}}\right)\right]-1\right\}+\phi^{\mathrm{h}}\left(e_{1}\right) \lambda_{\mathrm{L} 2}^{\mathrm{h}} \\
& \times\left\{\phi^{\mathrm{h}^{\prime}}\left(e_{2}^{\mathrm{b}}\right)\left[V\left(f\left(R^{\mathrm{h}}\right)+h\left(R^{\mathrm{h}}\right)+R^{\mathrm{h}}\right)-V\left(R^{\mathrm{h}}\right)\right]-1\right\},
\end{aligned}
$$

with respect to $e_{1}, T_{\mathrm{L} 1}^{\mathrm{h}}, R^{\mathrm{h}}$ and $\lambda_{\mathrm{L} 1}$. Differentiation with respect to $e_{1}, T_{\mathrm{L} 1}^{\mathrm{h}}, R^{\mathrm{h}}$ and $\lambda_{\mathrm{L} 1}$ results in

$$
\begin{aligned}
& e_{1}: \phi^{\mathrm{h}^{\prime}}\left(e_{1}\right)\left\{\left[b\left(x_{1}^{\mathrm{h}}-x_{1}^{\mathrm{L}}\right)-T_{1}^{\mathrm{h}}-R^{\mathrm{h}}\right]+\left(\mathrm{E} U_{\mathrm{P} 2}^{\mathrm{h}}-\mathrm{E} U_{\mathrm{P} 2}^{\mathrm{L}}\right)\right\} \\
& \quad+\lambda_{\mathrm{L} 1} \phi^{\mathrm{h}^{\mathrm{h}}}\left(e_{1}\right)\left[V\left(T_{\mathrm{L} 1}^{\mathrm{h}}+T_{\mathrm{s} 1}^{\mathrm{h}}\right)+\beta \Delta \mathrm{E} U_{\mathrm{A} 2}^{\mathrm{h}}\left(R^{\mathrm{b}}\right)\right]=0, \\
& T_{\mathrm{L} 1}^{\mathrm{h}}:-\phi^{\mathrm{h}}\left(e_{1}\right)+\lambda_{\mathrm{L} 1} \phi^{\mathrm{h}^{\prime}}\left(e_{1}\right) V^{\prime}\left(T_{\mathrm{L} 1}^{\mathrm{h}}+T_{\mathrm{s} 1}^{\mathrm{h}}\right)=0, \\
& R^{\mathrm{h}}:-\phi^{\mathrm{h}}\left(e_{1}\right)\left[1+\phi^{\mathrm{h}}\left(e_{2}^{\mathrm{h}}\right) f^{\prime}\left(R^{\mathrm{h}}\right)\right]+\lambda_{\mathrm{L} 1} \beta \phi^{\mathrm{h}^{\prime}}\left(e_{1}\right) \\
& \quad \times\left\{\phi^{\mathrm{L}}\left(e_{2}^{\mathrm{h}}\right) V^{\prime}\left(R^{\mathrm{h}}\right)+\phi^{\mathrm{h}}\left(e_{2}^{\mathrm{h}}\right) V^{\prime}\left(T_{\mathrm{L} 2}^{\mathrm{hh}}+T_{\mathrm{s} 2}^{\mathrm{hh}}+R^{\mathrm{h}}\right)\right. \\
& \left.\quad+\phi^{\mathrm{h}}\left(e_{2}^{\mathrm{h}}\right) V^{\prime}\left(T_{\mathrm{L} 2}^{\mathrm{hh}}+T_{\mathrm{s} 2}^{\mathrm{hh}}+R^{\mathrm{h}}\right)\left(f^{\prime}\left(R^{\mathrm{h}}\right)+h^{\prime}\left(R^{\mathrm{h}}\right)\right)\right\} \\
& \quad+\lambda_{\mathrm{L} 2}^{\mathrm{h}} \phi^{\mathrm{h}}\left(e_{1}\right) \phi^{\mathrm{h}}\left\{( e _ { 2 } ^ { \mathrm { h } } ) \left[V^{\prime}\left(T_{\mathrm{L} 2}^{\mathrm{hh}}+T_{\mathrm{s} 2}^{\mathrm{hh}}+R^{\mathrm{h}}\right)\right.\right. \\
& \left.\left.\quad-V^{\prime}\left(R^{\mathrm{b}}\right)\right]+V^{\prime}\left(T_{\mathrm{L} 2}^{\mathrm{hh}}+T_{\mathrm{s} 2}^{\mathrm{hh}}+R^{\mathrm{h}}\right)\left(f^{\prime}\left(R^{\mathrm{h}}\right)+h^{\prime}\left(R^{\mathrm{h}}\right)\right)\right\}=0, \\
& \lambda_{\mathrm{L} 1}: \phi^{\mathrm{h}^{\prime}}\left(e_{1}\right)\left[V\left(T_{\mathrm{L} 1}^{\mathrm{h}}+T_{\mathrm{s} 1}^{\mathrm{h}}\right)+\beta \Delta \mathrm{E} U_{\mathrm{A} 2}^{\mathrm{h}}\left(R^{\mathrm{h}}\right)\right]-1=0 .
\end{aligned}
$$

Replacing $\lambda_{\mathrm{L} 1}$ and $\lambda_{\mathrm{L} 2}^{\mathrm{h}}$ from L's first-order conditions in the first and second periods respectively, the first-order condition with respect to $R^{\mathrm{h}}$ becomes

$$
\begin{aligned}
& \phi^{\mathrm{h}}\left(e_{1}\right)\left[-1+\beta \phi^{\mathrm{h}}\left(e_{2}^{\mathrm{h}}\right) \frac{V^{\prime}\left(T_{\mathrm{L} 2}^{\mathrm{hh}}+T_{\mathrm{s} 2}^{\mathrm{hh}}+R^{\mathrm{h}}\right)}{V^{\prime}\left(T_{\mathrm{L} 1}^{\mathrm{h}}+T_{\mathrm{s} 1}^{\mathrm{h}}\right)}\right. \\
& \left.+\beta \phi^{\mathrm{L}}\left(e_{2}^{\mathrm{h}}\right) \frac{V^{\prime}\left(R^{\mathrm{h}}\right)}{V^{\prime}\left(T_{\mathrm{L} 1}^{\mathrm{h}}+T_{\mathrm{s} 1}^{\mathrm{h}}\right)}+\phi^{\mathrm{h}}\left(e_{2}^{\mathrm{h}}\right)\left(1-\frac{V^{\prime}\left(R^{\mathrm{h}}\right)}{V^{\prime}\left(T_{\mathrm{L} 2}^{\mathrm{hh}}+T_{\mathrm{s} 2}^{\mathrm{hh}}+R^{\mathrm{h}}\right)}\right)\right] \\
& +\phi^{\mathrm{h}}\left(e_{1}\right) \phi^{\mathrm{h}}\left(e_{2}^{\mathrm{h}}\right) \beta \frac{V^{\prime}\left(T_{\mathrm{L} 2}^{\mathrm{hh}}+T_{\mathrm{s} 2}^{\mathrm{hh}}+R^{\mathrm{h}}\right)}{V^{\prime}\left(T_{L 1}^{\mathrm{h}}+T_{s 1}^{\mathrm{h}}\right)}\left(f^{\prime}\left(R^{\mathrm{h}}\right)+h^{\prime}\left(R^{\mathrm{h}}\right)\right) \\
& +\phi^{\mathrm{h}}\left(e_{1}\right)^{\prime} \phi^{\mathrm{h}}\left(e_{2}^{\mathrm{h}}\right) h^{\prime}\left(R^{\mathrm{h}}\right)=0 .
\end{aligned}
$$

\section{A.3. Equilibrium in period two with two principals: Opposed interests. ${ }^{53}$}

Totally differentiating Eqs. (10), (11) and (12), and after replacing $\left[b\left(x_{2}^{\mathrm{h}}-x_{2}^{\mathrm{L}}\right)\right.$ $\left.-T_{\mathrm{L} 2}^{\mathrm{hh}}\right]$ and $\left[a\left(x_{2}^{\mathrm{L}}-x_{2}^{\mathrm{h}}\right)-T_{\mathrm{s} 2}^{\mathrm{hL}}\right]$ from $\mathrm{L}_{2}^{\mathrm{h}}$ and $\mathrm{S}_{2}^{\mathrm{h}}$ 's first-order conditions respec-

\footnotetext{
${ }^{53}$ We consider a utility function with constant absolute risk-aversion for computational simplicity.
} 
tively we obtain the system below:

$$
\begin{aligned}
& {\left[-\phi^{\mathrm{h}^{\prime}}+\frac{\phi^{\mathrm{h}^{\prime}} \phi^{\mathrm{h}^{\prime \prime}}}{\phi^{\mathrm{h}^{\prime}}}\left(2-\frac{\phi^{\mathrm{h}^{\prime}} \phi^{\mathrm{h}^{\prime \prime \prime}}}{\phi^{\mathrm{h}^{\prime 2} 2}}\right)\right] \mathrm{d} e_{2}^{\mathrm{h}}+\left\{\frac{-\phi^{\mathrm{h}^{\prime} 2} V^{\prime}\left(T_{\mathrm{L} 2}^{\mathrm{hh}}+R\right)}{\phi^{\mathrm{h}^{\prime \prime}} \Delta V}\left[\frac{\phi^{\mathrm{h}} \phi^{\mathrm{h}^{\prime \prime}}}{\phi^{\mathrm{h}^{\prime} 2}}-1\right]\right.} \\
& \left.+\phi^{\mathrm{h}} \frac{V^{\prime \prime}\left(T_{\mathrm{L} 2}^{\mathrm{hh}}+R\right)}{V^{\prime}\left(T_{\mathrm{L} 2}^{\mathrm{h}}+R\right)}\right\} \mathrm{d} T_{\mathrm{L} 2}^{\mathrm{hh}}+\frac{\phi^{\mathrm{h}} V^{\prime}\left(T_{\mathrm{L} 2}^{\mathrm{hh}}+R\right)}{\Delta V} \mathrm{~d} T_{\mathrm{s} 2}^{\mathrm{hL}}=0, \\
& {\left[\phi^{\mathrm{h}^{\prime}}+\frac{\phi^{\mathrm{L}} \phi^{\mathrm{h}^{\prime \prime}}}{\phi^{\mathrm{h}^{\prime}}}\left(2-\frac{\phi^{\mathrm{h}^{\prime}} \phi^{\mathrm{h}^{\prime \prime \prime}}}{\phi^{\mathrm{h}^{\prime \prime} 2}}\right)\right] \mathrm{d} e_{2}^{\mathrm{h}}-\frac{\phi^{\mathrm{L}} V^{\prime}\left(T_{\mathrm{s} 2}^{\mathrm{hL}}+R\right)}{\Delta V} \mathrm{~d} T_{\mathrm{L} 2}^{\mathrm{hh}}} \\
& +\left\{\frac{\phi^{\mathrm{h}^{\prime} 2} V^{\prime}\left(T_{\mathrm{s} 2}^{\mathrm{hL}}+R\right)}{\phi^{\mathrm{h}} \Delta V}\left[1+\frac{\phi^{\mathrm{L}} \phi^{\mathrm{h}^{\prime \prime}}}{\phi^{\mathrm{h}^{\prime} 2}}\left(\frac{V^{\prime \prime}\left(T_{\mathrm{s} 2}^{\mathrm{hL}}+R\right) \Delta V}{V^{\prime}\left(T_{\mathrm{s} 2}^{\mathrm{hL}}+R\right)^{2}}+1\right)\right]\right\} \mathrm{d} T_{\mathrm{s} 2}^{\mathrm{hL}}=0, \\
& \phi^{\mathrm{h}^{\prime \prime}} V \mathrm{~d} e_{2}^{\mathrm{h}}+\phi^{\mathrm{h}^{\prime}} V^{\prime}\left(T_{\mathrm{L} 2}^{\mathrm{h}}+R\right) \mathrm{d} T_{\mathrm{L} 2}^{\mathrm{h}}-\phi^{\mathrm{h}^{\prime}} V^{\prime}\left(T_{\mathrm{s} 2}^{\mathrm{hL}}+R\right) \mathrm{d} T_{\mathrm{s} 2}^{\mathrm{hL}}=-\phi^{\mathrm{h}^{\prime}} \Delta V^{\prime} \mathrm{d} R .
\end{aligned}
$$

Note that Assumptions 1 and 2 assure that the first term of the first (second) equation above is negative (positive), whereas the third term of the second equation is negative by Assumption 1 even if $V^{\prime \prime}=0$. Then, it is easy to check that the determinant is negative. It is also straightforward to show that $\partial e_{2}^{\mathrm{h}} / \partial R^{\mathrm{h}}$ and $\partial T_{\mathrm{s} 2}^{\mathrm{hL}} / \partial R^{\mathrm{h}}$ are negative. Finally, $\partial T_{\mathrm{L} 2}^{\mathrm{hh}} / \partial R^{\mathrm{h}}$ is positive if and only if

$$
\begin{aligned}
& \frac{\phi^{\mathrm{h}^{\prime}} V^{\prime}\left(T_{\mathrm{s} 2}+R\right)}{\Delta V}\left[\phi^{\mathrm{L}}+\frac{\phi^{\mathrm{h}^{2}}}{\phi^{\mathrm{h}^{\prime \prime}}}\right]+\frac{\phi^{\mathrm{L}} V^{\prime \prime}\left(T_{\mathrm{s} 2}+R\right)}{V^{\prime}\left(T_{\mathrm{s} 2}+R\right)} \\
& \times\left[\phi^{\mathrm{h}^{\prime}}-\frac{\phi^{\mathrm{h}} \phi^{\mathrm{h}^{\prime \prime}}}{\phi^{\mathrm{h}^{\prime}}}\left(2-\frac{\phi^{\mathrm{h}^{\prime} \mathrm{h}^{\mathrm{h}^{\prime \prime}}}}{\phi^{\mathrm{h}^{\prime \prime} 2}}\right)\right]+\frac{\phi^{\mathrm{h}} \phi^{\mathrm{h}^{\prime}} l V^{\prime}\left(T_{\mathrm{s} 2}+R\right)}{\Delta V}\left[\frac{\phi^{\mathrm{h}^{\prime}} \phi^{\mathrm{h}^{\prime \prime \prime}}}{\phi^{\mathrm{h}^{\mathrm{h}^{2}}}}-1\right]<0 .
\end{aligned}
$$

Assumptions 1 and 2 imply that the first two terms are negative and the last one is positive. Consider the two extreme cases.

(a) $\phi^{\mathrm{h}^{\prime}} \mathrm{h}^{\mathrm{h}^{\prime \prime}} / \phi^{\mathrm{h}^{\mathrm{n}} 2}=1$. Then $\partial T_{\mathrm{L} 2}^{\mathrm{hh}} / \partial R^{\mathrm{h}}$ is unambiguously positive.

(b) $\phi^{\mathrm{h}^{\prime} \mathrm{h}^{\mathrm{m}}} / \phi^{\mathrm{h}^{\prime \prime 2}}=2$. Then, since $V^{\prime \prime}\left(T_{\mathrm{s} 2}^{\mathrm{hL}}+R\right) \Delta V=V^{\prime}\left(T_{\mathrm{s} 2}^{\mathrm{hL}}+R\right) \Delta V^{\prime}$ because we are considering a utility function with constant risk-aversion, $\partial T_{\mathrm{L} 2}^{\mathrm{hh}} / \partial R^{\mathrm{h}} 1>0$ if and only if

$$
\frac{\phi^{\mathrm{h}^{\prime}} V^{\prime}\left(T_{\mathrm{s} 2}^{\mathrm{hL}}+R\right)}{\Delta V}\left[\phi^{\mathrm{L}} \frac{V^{\prime}\left(T_{\mathrm{L} 2}^{\mathrm{hh}}+R\right)}{V^{\prime}\left(T_{\mathrm{s} 2}^{\mathrm{hL}}+R\right)}+\phi^{\mathrm{h}}+\frac{\phi^{\mathrm{h}^{\prime 2}}}{\phi^{\mathrm{h}^{\prime \prime}}}\right]<0 .
$$

Since $V^{\prime}\left(T_{\mathrm{L} 2}^{\mathrm{th}}+R\right)<V^{\prime}\left(T_{\mathrm{s} 2}^{\mathrm{hL}}+R\right)$, a sufficient condition for $\partial T_{\mathrm{L} 2}^{\mathrm{hh}} / \partial R^{\mathrm{h}}>0$ is that $\left[1+\phi^{h^{\prime 2}} / \phi^{b^{\prime \prime}}\right] \leqslant 0$. We assume that this is the case. ${ }^{54}$

\footnotetext{
${ }^{54}$ If $\phi^{\mathrm{h}}(e)=2-e^{-1}$ (and $e \in(1 / 2,1)$ ) for instance, the condition is only satisfied for low $\phi^{\mathrm{h}}(e)$, with the range increasing as the utility function becomes more risk-averse.
} 

as 55

Lastly, the long lived principal's problem in period one can then be written

$$
\begin{aligned}
\max Z= & \left\{\phi^{\mathrm{L}}\left(e_{1}\right)\left[b x_{1}^{\mathrm{L}}+\phi^{\mathrm{L}}\left(e_{2}^{\mathrm{L}}\right) b x_{2}^{\mathrm{L}}+\phi^{\mathrm{h}}\left(e_{2}^{\mathrm{L}}\right)\left(b x_{2}^{\mathrm{h}}-T_{\mathrm{L} 2}^{\mathrm{Lh}}\right)\right]\right. \\
& +\phi^{\mathrm{h}}\left(e_{1}\right)\left[b x_{1}^{\mathrm{h}}-T_{\mathrm{L} 1}^{\mathrm{h}}-R^{\mathrm{h}}+\phi^{\mathrm{L}}\left(e_{2}^{\mathrm{h}}\right) b x_{2}^{\mathrm{L}}\right. \\
& \left.+\phi^{\mathrm{h}}\left(e_{2}^{\mathrm{h}}\right)\left(b x_{2}^{\mathrm{h}}-f\left(R^{\mathrm{h}}\right)\right]\right\} \\
& +\lambda_{\mathrm{L} 1}^{\mathrm{t}}\left(\phi^{\mathrm{h}^{\mathrm{h}}}\left(e_{1}\right)\left[V\left(T_{\mathrm{L} 1}^{\mathrm{h}}\right)-V\left(T_{\mathrm{s} 1}^{\mathrm{L}}\right)+\beta \Delta \mathrm{E} U_{\mathrm{A}_{2}}^{\mathrm{h}}\left(R^{\mathrm{h}}\right)\right]-1\right\} \\
& +\phi^{\mathrm{L}}\left(e_{1}\right) \lambda_{\mathrm{L} 2}^{L^{L}}\left\{\phi^{\mathrm{h}^{\prime}}\left(e_{2}^{\mathrm{L}}\right)\left[V\left(T_{\mathrm{L} 2}^{\mathrm{Lh}}\right)-V\left(T_{\mathrm{s} 2}^{\mathrm{LL}}\right)\right]-1\right\}+\phi^{\mathrm{h}}\left(e_{1}\right) \lambda_{\mathrm{L} 2}^{\mathrm{h}} \\
& \times\left\{\phi^{\mathrm{h}}\left(e_{2}^{\mathrm{h}}\right)\left[V\left(f\left(R^{\mathrm{h}}\right)+R^{\mathrm{h}}\right)-V\left(h\left(R^{\mathrm{h}}\right)+R^{\mathrm{h}}\right)\right]-1\right\},
\end{aligned}
$$

with respect to $e_{1}, T_{\mathrm{L} 1}^{\mathrm{b}}, R^{\mathrm{h}}$ and $\lambda_{\mathrm{L} 1}^{\prime}$, where

$$
\begin{aligned}
\Delta \mathrm{E} U_{\mathrm{A} 2}^{\mathrm{h}}\left(R^{\mathrm{h}}\right)= & \phi^{\mathrm{L}}\left(e_{2}^{\mathrm{h}}\right) V\left(h\left(R^{\mathrm{h}}\right)+R^{\mathrm{h}}\right)+\phi^{\mathrm{h}}\left(e_{2}^{\mathrm{h}}\right) V\left(f\left(R^{\mathrm{h}}\right)+R^{\mathrm{h}}\right) \\
& -\phi^{\mathrm{L}}\left(e_{2}^{\mathrm{L}}\right) V\left(T_{\mathrm{s} 2}^{\mathrm{LL}}\right)-\phi^{\mathrm{h}}\left(e_{2}^{\mathrm{L}}\right) V\left(T_{\mathrm{L} 2}^{\mathrm{L}}\right)-\left(e_{2}^{\mathrm{h}}-e_{2}^{\mathrm{L}}\right) \geqslant 0 .
\end{aligned}
$$

Thus, differentiation with respect to $e_{1}, T_{\mathrm{L} 1}^{\mathrm{h}}, R^{\mathrm{b}}$ and $\lambda_{1}^{\prime}$ results in

$$
\begin{aligned}
& e_{1}: \phi^{\mathrm{h}^{\prime}}\left(e_{1}\right)\left\{\left[b\left(x_{1}^{\mathrm{h}}-x_{1}^{\mathrm{L}}\right)-T_{1}^{\mathrm{h}}-R^{\mathrm{h}}\right]+\left(\mathrm{E} U_{\mathrm{P} 2}^{\mathrm{h}}-\mathrm{E} U_{\mathrm{P} 2}^{\mathrm{L}}\right)\right\} \\
& \quad+\lambda_{\mathrm{L} 1}^{\prime} \phi^{\mathrm{b}^{\prime \prime}}\left(e_{1}\right)\left[V\left(T_{\mathrm{L} 1}^{\mathrm{hb}}\right)-V\left(T_{\mathrm{s} 1}^{\mathrm{hL}}\right)+\beta \Delta \mathrm{E} U_{\mathrm{A} 2}^{\mathrm{h}}\left(R^{\mathrm{h}}\right)\right], \\
& T_{\mathrm{L} 1}^{\mathrm{h}}:-\phi^{\mathrm{h}}\left(e_{1}\right)+\lambda_{\mathrm{L} 1}^{\prime} \phi^{\mathrm{h}^{\mathrm{h}}}\left(e_{1}\right) V^{\prime}\left(T_{\mathrm{L} 1}^{\mathrm{h}}\right), \\
& R^{\mathrm{h}}:-\phi^{\mathrm{h}}\left(e_{1}\right)\left[1+\phi^{\mathrm{h}}\left(e_{2}^{\mathrm{h}}\right) f^{\prime}\left(R^{\mathrm{h}}\right)\right]+\lambda_{\mathrm{L} 1}^{\prime} \beta \phi^{\mathrm{h}^{\prime}}\left(e_{1}\right)\left\{\phi^{\mathrm{L}}\left(e_{2}^{\mathrm{h}}\right) V^{\prime}\left(T_{\mathrm{s} 2}^{\mathrm{hL}}+R^{\mathrm{h}}\right)\right. \\
& \quad+\phi^{\mathrm{h}}\left(e_{2}^{\mathrm{h}}\right) V^{\prime}\left(T_{\mathrm{L} 2}^{\mathrm{hh}}+R^{\mathrm{h}}\right)+\phi^{\mathrm{h}}\left(e_{2}^{\mathrm{h}}\right) V^{\prime}\left(T_{\mathrm{L} 2}^{\mathrm{hh}}+R^{\mathrm{h}}\right) f^{\prime}\left(R^{\mathrm{h}}\right) \\
& \left.\quad+\phi^{\mathrm{L}}\left(e_{2}^{\mathrm{h}}\right) V^{\prime}\left(T_{\mathrm{s} 2}^{\mathrm{hL}}+R^{\mathrm{h}}\right) h^{\prime}\left(R^{\mathrm{b}}\right)\right\}+\lambda_{\mathrm{L} 2}^{\mathrm{h}^{\prime}} \phi^{\mathrm{h}}\left(e_{1}\right) \phi^{\mathrm{h}^{\prime}}\left(e_{2}^{\mathrm{h}}\right)\left[V^{\prime}\left(T_{\mathrm{L} 2}^{\mathrm{hh}}+R^{\mathrm{h}}\right)\right. \\
& \left.\left.\quad-V^{\prime}\left(T_{\mathrm{s} 2}^{\mathrm{hL}}+R^{\mathrm{h}}\right)\right]+V^{\prime}\left(T_{\mathrm{L} 2}^{\mathrm{th}}+R^{\mathrm{h}}\right) f^{\prime}\left(R^{\mathrm{h}}\right)-V\left(T_{\mathrm{s} 2}^{\mathrm{hL}}+R^{\mathrm{b}}\right) h^{\prime}\left(R^{\mathrm{h}}\right)\right\}, \\
& \lambda_{\mathrm{L} 1}^{\prime}: \phi^{\mathrm{h}^{\prime}}\left(e_{1}\right)\left[V\left(T_{\mathrm{L} 1}^{\mathrm{h}}\right)-V\left(T_{\mathrm{s} 1}^{\mathrm{L}}\right)+\beta \Delta \mathrm{E} U_{\mathrm{A} 2}^{\mathrm{h}}\left(R^{\mathrm{h}}\right)\right]-1=0 .
\end{aligned}
$$

\section{References}

Adrian, Charles R., 1988, Forms of city government in American history, in: Municipal year book (Washington, DC).

Bernhein, Douglas B. and Michael D. Whinston, 1986, Common agency, Econometrica 54, no. 4, 923-942.

Biographical Directory of the United States Congress: 1774-1989, 1989 (U.S. Government Printing Office, Washington, DC)

\footnotetext{
${ }^{55}$ The superscripts () on the Lagrange multipliers do not denote derivatives. They just differentiate them from those in the previous section.
} 
Cox, Gary W., 1987, The efficient secret (Cambridge University Press, Cambridge).

Deutsch, Karl W., Jorge I. Dominguez and Hugh Heclo, 1981, Comparative government: Politics of industrialized and developing nations (Houghton Mifflin, Boston, MA).

Fainstein, Norman I. and Susan S. Fainstein, 1976, Urban political movements, in: Stephen M. David and Paul E. Peterson, eds., Urban politics and public policy, Second edition (Praeger, London).

Fesler, James W., 1983, The higher civil service in Europe and the United States, in: Bruce L.R. Smith, ed., The higher civil service of Europe and Canada: Lessons for the United States (The Brookings Institution, Washington, DC).

Fiorina, Morris P., 1986, Congress and bureaucracy: A profitable partnership, in: Francis E. Rourke, ed., Bureaucratic power in national policy making, Fourth edition (Little, Brown and Company, Boston, MA).

Fiorina, Morris P., 1990, An era of divided government, in: Bruce Cain and Gillian Peele, eds., Developments in American politics (Macmillan, London).

Garand, James and Donald A. Gross, 1984, Changes in the vote margins for congressional candidates: A specification of historical trends, American Political Science Review 78, 17-30.

Heclo, Hugh, 1977, A government of strangers (The Brookings Institution, Washington, DC).

Heclo, Hugh, 1983, A comment on the future of the U.S. civil service, in: Bruce L.R. Smith, ed., The higher civil service of Europe and Canada: Lessons for the United States (The Brookings Institution, Washington, DC).

Holmström, Bengt, 1979, Moral hazard and observability (The Bell Journal of Economics 10, no.1, 74-91.

International City Managers' Association, 1963, The municipal year book (Chicago, II).

International City Managers' Association, 1972, 1976, The municipal year book (Washington, DC).

Jacobson, Gary C., 1990, The electoral origins of divided government: Competition in US House elections, 1946-1988 (Westview Press, Boulder, CO).

Johnson, Ronald N. and Gary D. Libecap: Patronage to merit: Political change in the federal government labor force, Mimeo., Aug.

Kernell, Samuel, 1977, Toward understanding 19th Century congressional careers: Ambition, competition, and rotation, American Journal of Political Science 21, 669-693.

Kiewiet, D. Roderick and Matthew D. McCubbins, 1988, Presidential influence on congressional appropriations decisions, American Journal of Political Science 32, no. 3, 713-736.

Knott, Jack and Gary J. Miller, 1987, Reforming bureaucracy: The politics of institutional choice (Prentice Hall, Englewood Cliffs, NJ).

Laffont, Jean-Jacques and Jean Tirole, 1988, The politics of government decision-making: A theory of regulatory capture, Working paper no. 506 (M.I.T., Cambridge, MA).

Mainzer, Lewis C., 1973, Political bureaucracy (Scott, Foresman and Company, Glenview, IL).

Moe, Terry M., 1989, The politics of bureaucratic structure, in: John E. Chubb and Paul E. Peterson, eds., Can the government govern? (The Brookings Institution, Washington, DC).

Pfiffner, James P., 1987, Political appointees and career executives: The democracy-bureaucracy nexus in the Third Century, Public Administration Review, Jan./Feb., 57-65.

Radner, Roy, 1985, Repeated principal-agent games with discounting, Econometrica 53, no.5, 1173-1198.

Roberts, Geoffrey and Jill Lovecy, 1984, West European politics today (Manchester University Press, Manchester).

Rogerson, William P., 1985a, Repeated moral hazard, Econometrica 53, no.1, 1985a, 69-76.

Rogerson, William P., 1985b, The first-order approach to principal-agent problems, Econometrica 53, no.6, 1357-1367.

Rubinstein, Ariel and Manahem Yaari, 1983, Repeated insurance contracts and moral hazard, Journal of Economic Theory 30, 74-97.

Spiller, Pablo T., 1990, Politicians, interest groups, and regulators: A multiple-principals agency theory of regulation (or 'Let Them be Bribed'), Journal of Law and Economics XXXIII, no. 1, 65-101. 
Stahl, O. Glenn, 1971, Public personnel administration, 6th edition (Harper and Row, London).

Stanley, David T., 1983, Lessons for the United States, in: Bruce L.R. Smith, ed., The higher civil service of Europe and Canada: Lessons for the U.S. (The Brookings Institution, Washington, DC).

Stone, Clarence N., Robert K. Whelan and William J. Murin, 1979, Urban policy and politics (Prentice-Hall, Englewood Cliffs, NJ).

Urbiztondo, Santiago, 1990, Multiple principals, cost of switching actions and commitment: Human capital investment in the civil service, Mimeo.

U.S. Civil Service Commission, various issues, Annual reports, (USGPO, Washington, DC).

U.S. Department of Commerce, 1976, Historical statistics of the United States (USGPO, Washington, DC).

U.S. Department of Commerce, Bureau of Census, 1988, County and city data book (USGPO, Washington, $\mathbf{D C}$ ).

Van Ripen, Paul P., 1958, History of the United States civil service (Row, Peterson and Company, Evanston, IL).

Wilson, James Q., 1982, Bureaucracy: What government agencies do and why they do it (Basic Books, New York) 